\title{
Electrostatic self-assembled multilayers of tetrachromatedmetalloporphyrins/polyoxometalateand its electrocatalytic properties in oxygen reduction
}

\author{
Camilo García ${ }^{\mathrm{a}, \mathrm{c}}$, Carlos Díaz ${ }^{\mathrm{a}}$, Paulo Araya ${ }^{\mathrm{b}}$, Fabiola Isaacs ${ }^{\mathrm{c}}$, Guillermo Ferraudi ${ }^{\mathrm{d}}$, \\ Alexander G. Lappin ${ }^{\mathrm{e}}$, María Jesús Aguirre ${ }^{\mathrm{c}}$, Mauricio Isaacsa ${ }^{\mathrm{a}, *}$ \\ a Pontificia Universidad Católica de Chile, Facultad de Química, Departamento de Química Inorgánica, Av. Vicuña Mackenna 4860. Campus San Joaquín, \\ Macul, Santiago, Chile \\ ${ }^{\mathrm{b}}$ Universidad de Chile, Facultad de Ciencias Físicas y Matemáticas, Departamento de Ingeniería Química y Biotecnología, Av. Beaucheff 850, Santiago, Chile \\ ' Universidad de Santiago de Chile, Facultad de Química y Biología, Departamento de Química de los Materiales, Av. Libertador Bernardo O’Higgins 3363, \\ Estación Central, Santiago, Chile \\ d Notre Dame Radiation Laboratory, Notre Dame 46556, Indiana, U.S.A \\ e Chemistry \&' Biochemistry Department, University of Notre Dame, 46556, Indiana, U.S.A.
}

\section{A R T I C L E I N F O}

\section{Article history:}

Received 21 July 2014

Received in revised form 28 August 2014

Accepted 30 August 2014

Available online 18 September 2014

\section{Keywords:}

Tetrachromatedmetalloporphyrins

silicontungstate

layer by layer

oxygen reduction

non-precious catalyst

rotating ring-disk electrode.

\begin{abstract}
A B S T R A C T
Multilayer electrostatic assemblies described as $\left\{\left[\mathrm{FeTPyP}\left(\operatorname{Crphen}_{2} \mathrm{Cl}\right)_{4}\right]^{8+} / \mathrm{SiW}_{12} \mathrm{O}_{40}{ }^{4-}\right\}_{\mathrm{n}_{\mathrm{i}}}$ and $\left\{\left[\operatorname{NiTPyP}\left(\mathrm{Crphen}_{2} \mathrm{Cl}\right)_{4}\right]^{8+} / \mathrm{SiW}_{12} \mathrm{O}_{40}{ }^{4-}\right\}_{\mathrm{n}_{\mathrm{i}}}$, where TPyP $=5,10,15,20$-tetra(4-pyridyl) porphyrin, phen $=1$, 10-phenanthroline, $\mathrm{SiW}_{12} \mathrm{O}_{40}{ }^{4-}=$ silicontungstate and $\mathrm{n}_{\mathrm{i}}=$ number of multilayers, were assembled onto different electrodic surfaces. The modified electrodes were constructed using the layer by layer methodology. UV-Vis spectroscopy, scanning electron microscopy (SEM), and cyclic voltammetry were used for the electrodes characterization. The electrocatalytically reduction of oxygen in aqueous solution was driven with these electrodes. In the oxygen reduction, rotating ring-disk and cyclic voltammetry techniques revealed a synergic effect between the cationic porphyrin and $\mathrm{SiW}_{12} \mathrm{O}_{40}{ }^{4-}$. The synergism is related to the number of multilayers, the porphyrin complex employed, inner electroactive process across assemblies and the overpotential applied in the electrochemical process.
\end{abstract}

(c) 2014 Elsevier Ltd. All rights reserved.

\section{Introduction}

The oxygen reduction reaction (ORR) is a key process in energy conversion and storage for fuel cells, metal-air batteries among others [1]. Pt has been used for a long time in real technological applications as electrocatalyst, however its scarcity, high price, sluggish ORR process, intolerance to fuel crossover and instability, have been some of the principal barriers for global applications of the fuel cell technology as a substituent of fossil fuels [1-5].

To fulfill the needs of a global hydrogen economy, current research efforts are directed toward the design of catalysts made of cheap and abundant elements [6-8]. This is a primary condition for a hydrogen economy based in fuel cell technologies $[9,10]$.

$\mathrm{N}_{4}$-macrocyclics as porphyrins and phthalocyanines of transition metal ions have properties suitable for this goal [11]. Nature has used abundant metalloporphyrins with transition metal ions

\footnotetext{
* Corresponding author.

E-mail address: misaacs@uc.cl (M. Isaacs).
}

such as $\mathrm{Fe}, \mathrm{Co}, \mathrm{Cu}, \mathrm{Mn}$, for thecatalysis of energy conversion processes. Examples of these catalyzed processes are the oxygen evolution from water in plants photosynthesis, oxygen reduction, nitrogen fixation, sulfate reduction $[9,12]$.

On the other hand, polyoxometalates are supramolecular clusters formed by nanostructured metallic oxides which ratio is $\sim 1 \mathrm{~nm}$ [13]. Because their high electronic density, they have high potentiality in multielectronic transfer and photophysical applications [14], which it motivates the design and development of functional materials and several devices based in this polymetallic anions $[15,16]$. Indeed, they can interact strongly with cationic porphyrins, creating new hybrids materials very useful in different micro and/or nanostructured composites [17-21] or in layer by layer hybrids $[16,20-30]$ with application as sensors, electrocatalysts and optical devices [24,31].

Our group have employed $\mathrm{N}_{4}$-macrocyclics in several arrangements as conducting polymer [32-35], electrostatic assemblies [30], and composites and studied its properties as electrocatalyst and sensor [36-39]. In a previous work, it was reported the synthesis and characterization of a class of porphyrins, where 
$5,10,15,20$ tetra-pyridylporphyrin was coordinated to four equivalent $\left[\mathrm{Cr}(\text { phen })_{2} \mathrm{Cl}\right]^{2+}$ groups, with $\mathrm{Fe}(\mathrm{II})$ and $\mathrm{Ni}(\mathrm{II})$ in the central macrocyclic cavity i.e $\left[\mathrm{M}^{(\mathrm{II})} \mathrm{TPyP}\left(\mathrm{Crphen}_{2} \mathrm{Cl}\right)_{4}\right]^{8+}$ cation [40], in order to obtain a new class of multimetallicmacrocyclics with non-precious metals. However the high charge of such cationic macrocyclics must be considered to study such porphyrins onto an electrodic surface in aqueous media, in a similar way as other cationic species $[41,42]$.

Layer by layer methodology have been proposed as a reliable tool to control the material adsorbed onto the electrode only by simple consecutive immersion in solutions of the compound of interest, it can be obtained self-assembled multilayers systems with interesting synergic effects [41-43].

Based in these facts, in this work, we have explored if the "layer-by-layer" methodology can be employed to design a $\left[\mathrm{M}^{(\mathrm{II})} \mathrm{TPyP}\left(\text { Crphen }_{2} \mathrm{Cl}\right)_{4}\right]^{8+} \mathrm{SiW}_{12} \mathrm{O}_{40}{ }^{4-}$ modified electrode, and its electrocatalytic properties of such non-precious metallic hybrids in oxygen reduction.

\section{Experimental}

\subsection{Reagents}

$5,10,15,20$ tetra-(4-pyridyl)-21H,23H-porphine, trifluoromethanesulfonic acid $99.99 \%$, chromium (III) chloride hexahydrate, $\mathrm{Fe}\left(\mathrm{CH}_{3} \mathrm{COO}\right)_{2}, \mathrm{Ni}\left(\mathrm{CH}_{3} \mathrm{COO}\right)_{2}$ and 1,10-phenanthroline monohydrate were purchased from Sigma-Aldrich and they were used as received. Sodium perchlorate and $\mathrm{H}_{4} \mathrm{SiW}_{12} \mathrm{O}_{40}$ were purchased from Fluka. $0.1 \mathrm{M} \mathrm{NaClO}_{4}$ was employed as supporting electrolyte in a Britton-Robinson solution, consisting of $0.04 \mathrm{M}$ $\mathrm{CH}_{3} \mathrm{COOH}, 0.04 \mathrm{M} \mathrm{H}_{3} \mathrm{BO}_{3}$ and $0.04 \mathrm{M} \mathrm{H}_{3} \mathrm{PO}_{4}$. The $\mathrm{pH}$ of the BrittonRobinson solutions was adjusted with $0.1 \mathrm{M} \mathrm{NaOH}$. Acetonitrile (ACN) was purchased from Merck and it was conveniently dried by distillation in presence of $\mathrm{CaH}_{2}$ [44]. The distilled solvent was

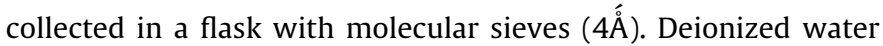
$(18.2 \mathrm{M} \Omega$ ) was obtained from a MiliQ deionizer, and it was used for the preparation of all aqueous solutions.

Synthesis of $\left.\left[\mathrm{FeTPyP}\left(\mathrm{Crphen}_{2} \mathrm{Cl}_{4}\right)_{[}\right] \mathrm{PF}_{6}\right]_{8}$ and [NiTPyP $\left.\left(\text { Crphen }_{2} \mathrm{Cl}\right)_{4}\right]\left[\mathrm{PF}_{6}\right]_{8}$ complexes were published in a previous work [40].

\subsection{Equipments and cells}

UV-Vis spectroscopy was registered in a Shimadzu Multispec 1501 photodiode array spectrophotometer. To study the generation of layer by layer assemblies onto ITO electrode, a quartz cell of $1.0 \mathrm{~cm}$ was used, where ITO modified electrodes were inserted in a Teflon cap. The UV-Vis spectrum was recorded in solid state. SEM micrographs were obtained with a scanning electron microscope LEO 1420VP. A potentiostast $\mathrm{CH}$-Instrument 760c was employed in all electrochemical studies. In the cyclic voltammetry, a one-compartment cell with a three electrodes arrangement was used, where the working electrode was a glassy carbon disk $(\mathrm{CH}-$ Intruments, $2 \mathrm{~mm}$ diameter), the reference electrode was $\mathrm{Ag} / \mathrm{AgCl}$ in $3 \mathrm{M} \mathrm{KCl}$ solution, and a platinum wire was used as auxiliary electrode ( $\mathrm{CH}$-Instruments). For rotating disk experiments a bipotentiostast $\mathrm{CHI} 900 \mathrm{~b}$ was connected in series with the rotating unit Radiometer Copenhagen CTV 101 and a PINE rotating disk speed control AFMSRCE instrument control. A glassy carbon electrode disk of $0.071 \mathrm{~cm}^{2}$ was used as working electrode. For rotating ring-disk experiment a PINE rotating ring-disk speed control unit AFMSRCE. The collection efficiency $(\mathrm{N}=0.23)$ for the glassy carbon disk and the platinum ring was determined in previous reports with $\left[\mathrm{Fe}(\mathrm{CN})_{6}\right]^{-3} /\left[\mathrm{Fe}(\mathrm{CN})_{6}\right]^{-4}$ as redox probe $[45,46]$. ITO electrodes were purchased from delta $(7 \mathrm{mmx} 2 \mathrm{~cm})$ technologies and were used in

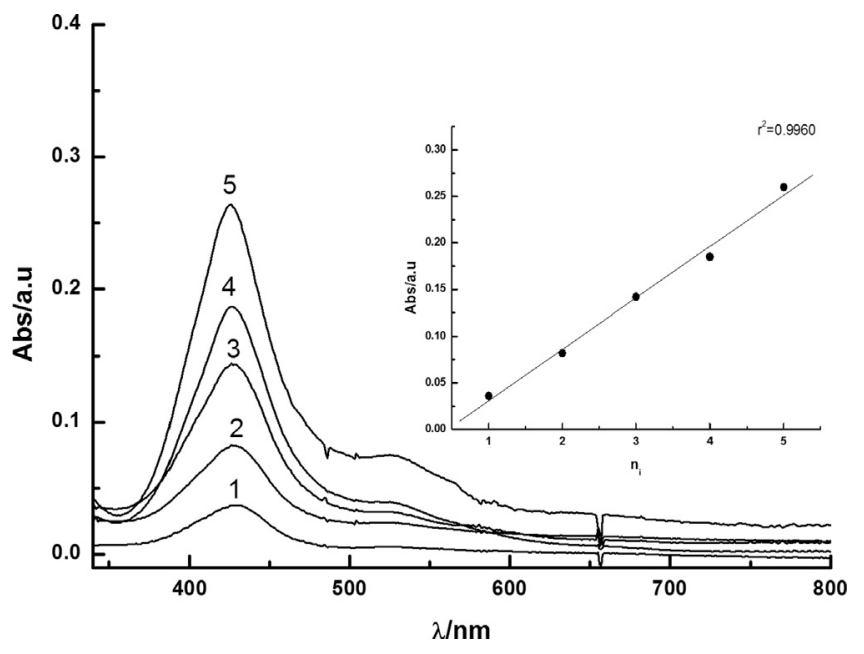

Fig. 1. UV-Vis spectra of $\left\{\left[\mathrm{FeTPyP}\left(\operatorname{Crphen}_{2} \mathrm{Cl}\right)_{4}\right]^{8+} / \mathrm{SiW}_{12} \mathrm{O}_{40}{ }^{4-}\right\}_{\mathrm{n}_{\mathrm{i}}} /$ ITO multilayers, where $n_{i}=1-5$. Inset: Absorbance of the Soret band of $\left\{\left[\mathrm{FeTPyP}\left(\mathrm{Crphen}_{2} \mathrm{Cl}\right)_{4}\right]^{8+} /\right.$ $\left.\mathrm{SiW}_{12} \mathrm{O}_{40}{ }^{4-}\right\}_{\mathrm{n}_{\mathrm{i}}} /$ ITO multilayers as ma function of $\mathrm{n}$.

spectroscopy and microscopy studies. A three compartment cell was employed for both rotating disk and rotating ring-disk techniques. All electrochemical experiments were performed at $25^{\circ} \mathrm{C}$.

\subsection{Electrode modification}

To generate a replicable protocol, both glassy carbon and ITO electrode were immersed in an acetonitrile solution of the required complex, $2.0 \times 10^{-4} \mathrm{M}$ of $\left[\mathrm{FeTPyP}\left(\mathrm{Crphen}_{2} \mathrm{Cl}\right)_{4}\right]\left[\mathrm{PF}_{6}\right]_{8}$ or $\left[\mathrm{NiTPyP}\left(\mathrm{Crphen}_{2} \mathrm{Cl}\right)_{2}\right]\left[\mathrm{PF}_{6}\right]_{8}$ in acetonitrile, at a constant rate of $0.083 \mathrm{~cm} / \mathrm{s}$. The electrode was dipped for 3 minutes. The electrode was rinsed with abundant deionized water and dried for 4 minutes at room temperature. Then, the same area of the electrode was immersed in a $0.5 \mathrm{mM} \mathrm{H}_{4} \mathrm{SiW}_{12} \mathrm{O}_{40}$ aqueous solution for 2 minutes at a constant rate of $0.083 \mathrm{~cm} / \mathrm{s}$, and picked up at the same velocity, washed with deionized water and dried at room temperature for 4 minutes. The process mentioned above was repeated to generate a high number of multilayers as can be seen in Scheme 1 . $\mathrm{SiW}_{12} \mathrm{O}_{40}{ }^{4-}$ was left as the outer layer in each modification. In the case of glassy carbon, after each modification, the electrode was turned exposing the wet surface to air. Then the droplet generated was rinsed with deionized water. A freshly prepared electrode was used for each experiment.

\section{Results and Discussion}

\subsection{Characterizationof electrostatic multilayers of $\left\{\left[\text { FeTPyP }\left(\text { Crphen }_{2} \mathrm{Cl}\right)_{4}\right]^{8+} / \mathrm{SiW}_{12} \mathrm{O}_{40}{ }^{4-}\right\}_{n_{i}}$ and $\left\{\left[\operatorname{NiTPyP}\left(\text { Crphen }_{2} \mathrm{Cl}\right)_{4}\right]^{8+} / \mathrm{SiW}_{12} \mathrm{O}_{40}{ }^{4-}\right\}_{n_{i}}$.}

\subsubsection{UV-Vis spectroscopy}

UV-Vis spectroscopy as a complementary technique was used to demonstrate the deposition of both porphyrin and polyoxometalate onto ITO electrodes via electrostatic assemblages $[24,25,29,30,47,48]$. Fig. 1 shows the UV-Vis spectra of the electrostatic assemblies $\left\{\left[\text { FeTPyP }\left(\mathrm{Crphen}_{2} \mathrm{Cl}\right)_{4}\right]^{8+} / \mathrm{SiW}_{12} \mathrm{O}_{40}{ }^{4-}\right\}_{\mathrm{n}_{\mathrm{i}}} /$ ITO, being silicontungstate the most outer layer of the assembly and $n_{i}$ the number of immersions. Absorption bands with $\lambda_{\max }=424 \mathrm{~nm}$ and $\lambda_{\max }=530 \mathrm{~nm}$ can be observed in the spectra. Both bands are associated with $\pi-\pi^{*}$ electronic transition centered in the porphyrin macrocycle and known respectively as Soret and Q bands. At these wavelengths, the absorbance increases with $n_{i}$ from $n_{i}=1$ to $n_{i}=5$, showing a well-arranged layer by layer packing $[47,49]$. 


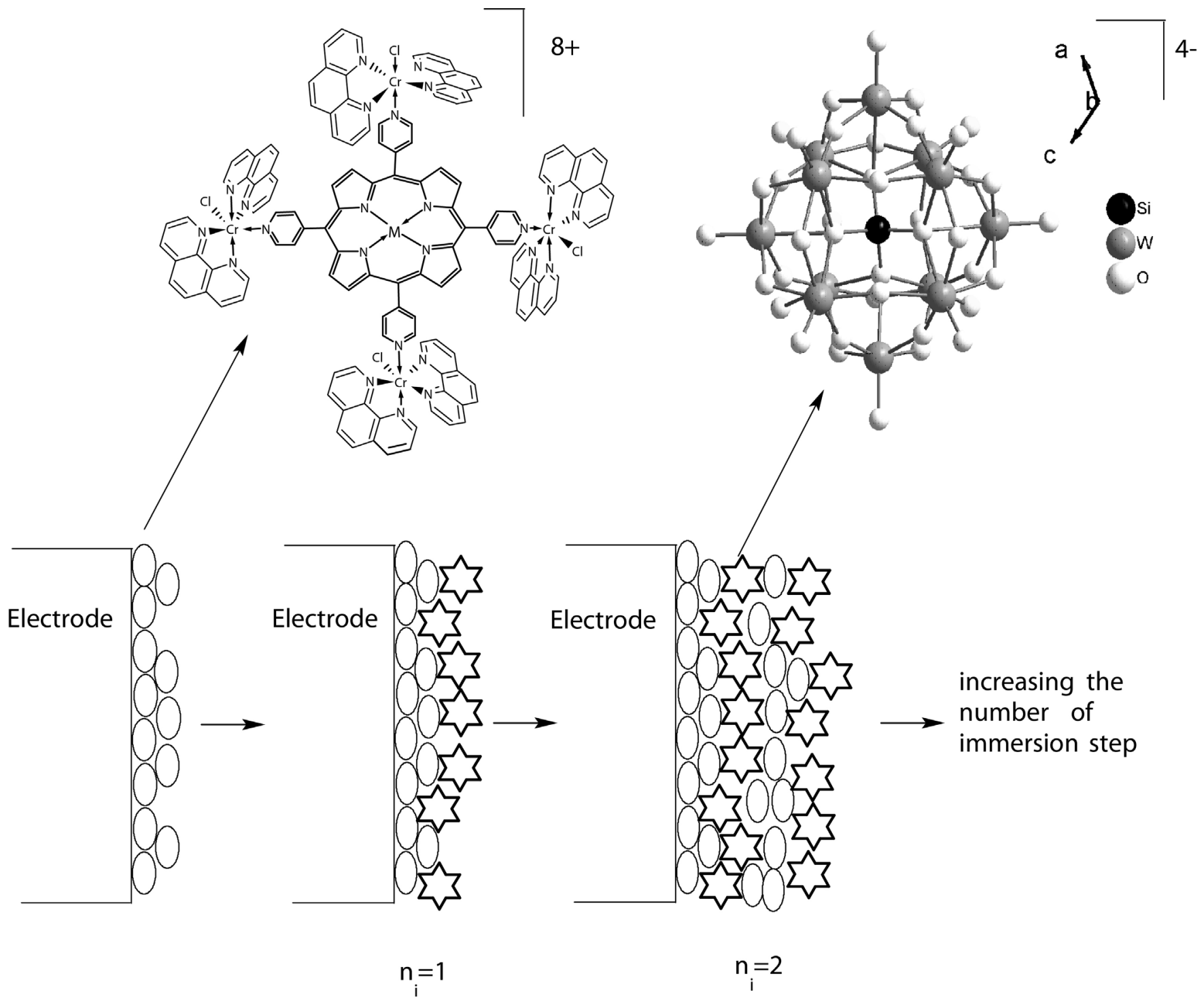

Scheme 1. Multilayer $\left\{\left[\mathrm{MTPyP}\left(\mathrm{Crphen}_{2} \mathrm{Cl}\right)_{4}\right]^{8+} / \mathrm{SiW}_{12} \mathrm{O}_{40}{ }^{4-}\right\}_{\mathrm{n}_{\mathrm{i}}}(\mathrm{M}=\mathrm{Fe}(\mathrm{II}), \mathrm{Ni}(\mathrm{II}))$ generation. In the figure, $\mathrm{n}_{\mathrm{i}}$ corresponds to the multilayers number of alternate depositions.

In a similar way, Fig. 2 shows an increase in the absorbance of $\left\{\left[\operatorname{NiTPyP}\left(\text { Crphen }_{2} \mathrm{Cl}\right)_{4}\right]^{8+} / \mathrm{SiW}_{12} \mathrm{O}_{40}{ }^{4-}\right\}_{\mathrm{n}_{\mathrm{i}}} /$ ITO with $\mathrm{n}_{\mathrm{i}}$ varying from $\mathrm{n}_{\mathrm{i}}=1$ to $\mathrm{n}_{\mathrm{i}}=5$.

The spectrum of the first multilayer $\{$ NiTPyP $\left.\left.\left(\text { Crphen }_{2} \mathrm{Cl}\right)_{4}\right]^{8+} / \mathrm{SiW}_{12} \mathrm{O}_{40}{ }^{4-}\right\}_{1} /$ ITOshows the Soret band positioned at $\lambda_{1 \max }=400 \mathrm{~nm}$. There is a shift to a different wavelength in comparison to $\left\{\left[\mathrm{NiTPyP}\left(\mathrm{Crphen}_{2} \mathrm{Cl}\right)_{4}\right]^{8+} / \mathrm{SiW}_{12} \mathrm{O}_{40}{ }^{4-}\right\}_{2-5} / \mathrm{ITO}$, where the maximum absorption is at $\lambda_{2-5 \max }=424 \mathrm{~nm}$. Moreover, the hybrid porphyrin/polyoxometalate assemblies have a broad and red shifted Soret band in comparison to the spectrum in solution. These changes are associated with the generation of porphyrin/polyoxometalate aggregates, as it is the case with other cationic porphyrin/polyoxometalate multilayers onto ITO surface $[24,25]$. It has been demonstrated already that cationic porphyrins are able to form aggregates which are stabilized through $\pi-\pi$ and cationic- $\pi$ interactions [50-52]. Similar interactions must help to stabilize the porphyrin/polyoxometalate aggregates describedabove.

At wavelengths of the Soret Band, the linear increase of the absorbance with the number of multilayers provides evidence of a mixed growth of the $\left\{\left[\operatorname{NiTPyP}\left(\operatorname{Crphen}_{2} \mathrm{Cl}\right)_{4}\right]^{8+} / \mathrm{SiW}_{12} \mathrm{O}_{40}{ }^{4-}\right\}_{\mathrm{n}_{\mathrm{i}}} /$ ITO multilayers, (insets to Figs. 1 and 2). It is a consequence of a layer

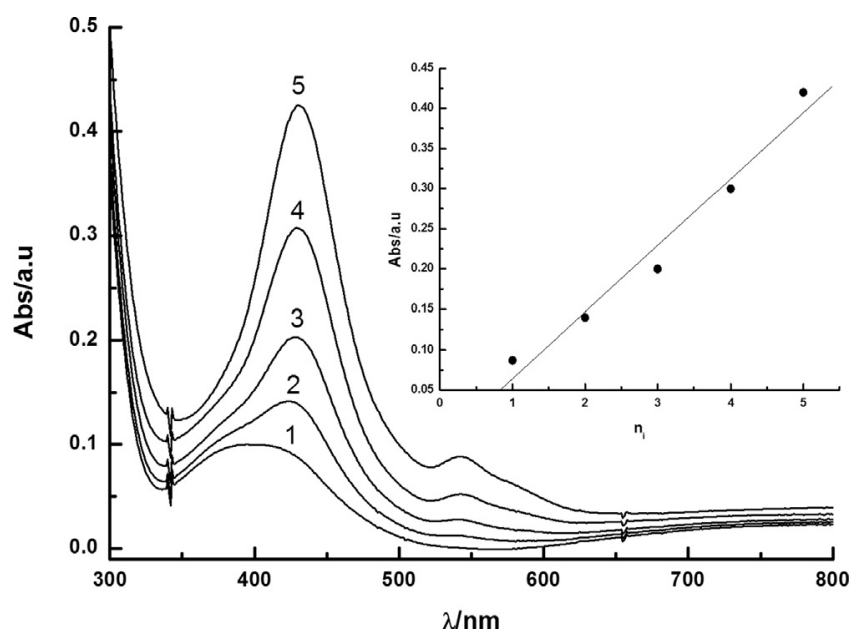

Fig. 2. UV-Vis spectra of $\left\{\left[\operatorname{NiTPyP}\left(\mathrm{Crphen}_{2} \mathrm{Cl}\right)_{4}\right]^{8+} / \mathrm{SiW}_{12} \mathrm{O}_{40}{ }^{4-}\right\}_{\mathrm{n}_{\mathrm{i}}} / \mathrm{ITO}$ multilayers, where $n_{i}=1-5$. Inset: Absorbance of Soret band of $\left\{\left[\operatorname{NiTPyP}\left(\operatorname{Crphen}_{2} \mathrm{Cl}_{4}\right]^{8+} /\right.\right.$ $\left.\mathrm{SiW}_{12} \mathrm{O}_{40}{ }^{4-}\right\}_{\mathrm{n}_{\mathrm{i}}} / / \mathrm{TTO}$ multilayers as a function of $\mathrm{n}_{\mathrm{i}}$. 

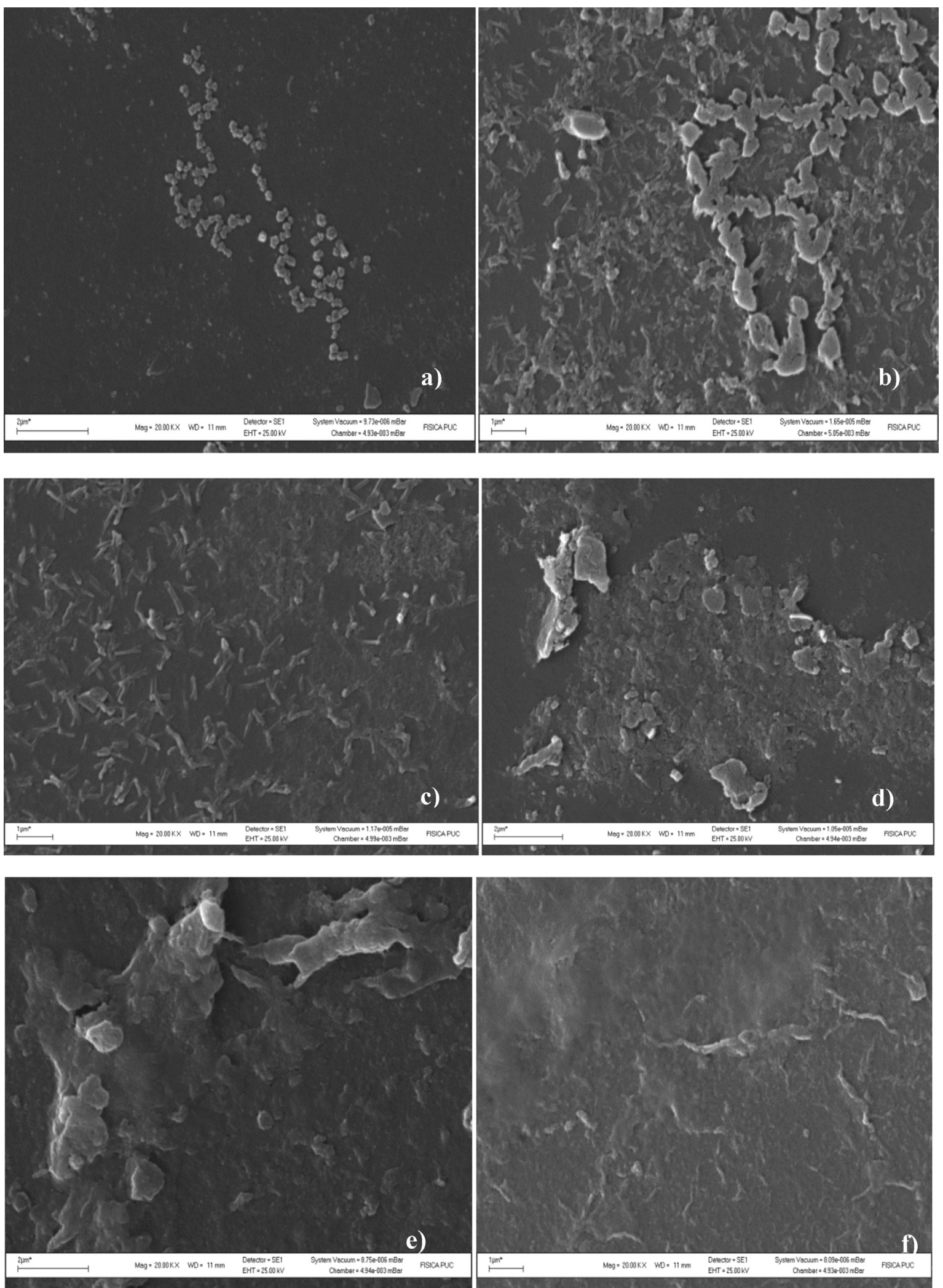

Fig. 3. SEM micrograph ofmultilayers electrostatically assembled: $\left\{\left[\operatorname{NiTPyP}\left(\operatorname{Crphen}_{2}\right)_{4}\right]^{8+} / \operatorname{SiW}_{12} \mathrm{O}_{40}{ }^{4-}\right\}_{n_{i}} / \operatorname{ITO}$ : a) $\left.\left.n_{i}=1, \quad b\right) n_{i}=2, \quad c\right) n_{i}=3,\left\{\left[F e T P y P\left(C r p h e n_{2}\right)_{4}\right]^{8+} /\right.$ $\left.\mathrm{SiW}_{12} \mathrm{O}_{40}{ }^{4-}\right\}_{n_{\mathrm{i}}} /$ ITO: d) $\left.\mathrm{n}_{\mathrm{i}}=1, \mathrm{e}\right) \mathrm{n}_{\mathrm{i}}=2$, f) $\mathrm{n}_{\mathrm{i}}=3$.

upon layer packing with lateral components $[49,53]$. In contrast to this assemblage, $\left\{\left[\mathrm{FeTPyP}\left(\operatorname{Crphen}_{2} \mathrm{Cl}\right)_{4}\right]^{8+} / \mathrm{SiW}_{12} \mathrm{O}_{40}{ }^{4-}\right\}_{\mathrm{n}_{\mathrm{i}}} /$ ITO $\left(n_{i}=1\right.$ to 5$)$ only undergoes a layer by layer packing which causes no shift of the Soret band maximum.

\subsubsection{Scanning electron microscopy}

SEM micrography for both systems shows interesting patterns in the early multilayer formation steps. $\left\{\left[\operatorname{NiTPyP}\left(\operatorname{Crphen}_{2} \mathrm{Cl}\right)_{4}\right]^{8+} /\right.$ $\left.\mathrm{SiW}_{12} \mathrm{O}_{40}{ }^{4-}\right\}_{1} /$ ITO, Fig. 3a, presents dispersed particles associated with this system. The presence of small aggregates, with a mean 


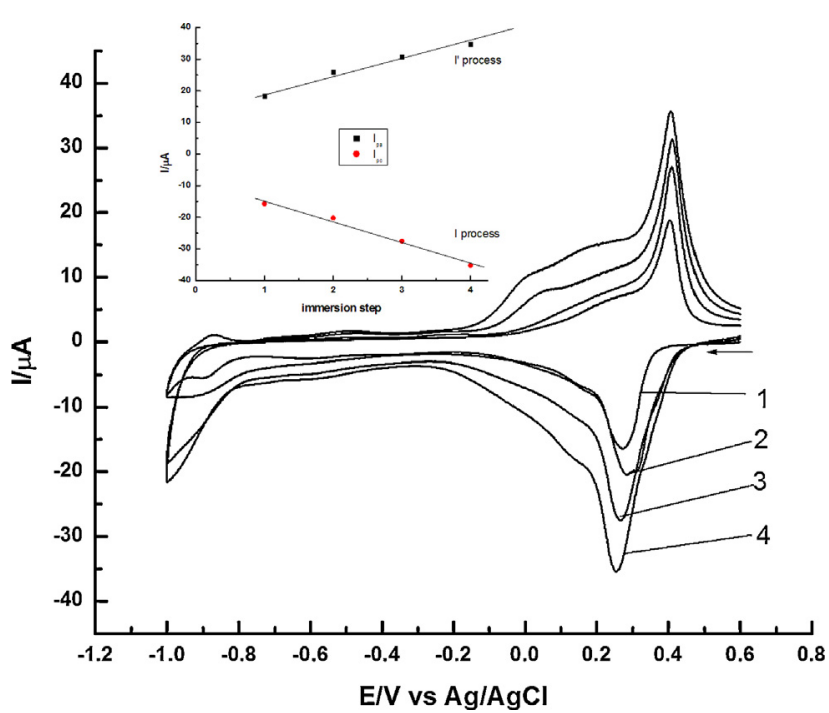

Fig. 4. Cyclic voltammetry of $\left\{\left[\mathrm{FeTPyP}\left(\mathrm{Crphen}_{2} \mathrm{Cl}\right)_{4}\right]^{8+} / \mathrm{SiW}_{12} \mathrm{O}_{40}{ }^{4-}\right\}_{\mathrm{n}_{\mathrm{i}}} / \mathrm{GC}$ multilayers $\left(n_{i}=1\right.$ to $\left.n_{i}=4\right)$. Scan rate $100 \mathrm{mV} / \mathrm{s}$. $0.1 \mathrm{M} \mathrm{NaClO}_{4}$. Inset: current peak $\mathrm{i}_{\mathrm{pa}}$ (I' process) and $\mathrm{i}_{\mathrm{pc}}$ (I process) vs $\mathrm{n}_{\mathrm{i}}$ multilayer number.

diameter of $266 \mathrm{~nm}$, demonstrates that $\left\{\left[\operatorname{NiTPyP}\left(\operatorname{Crphen}_{2} \mathrm{Cl}\right)_{4}\right]^{8+} /\right.$ $\left.\mathrm{SiW}_{12} \mathrm{O}_{40}{ }^{4-}\right\}_{1} /$ ITO is not a layer by layer structure.

A growth over earlier deposited particles can be observed as the number of depositions in the system $\left\{\left[\operatorname{NiTPyP}\left(\operatorname{Crphen}_{2} \mathrm{Cl}\right)_{4}\right]^{8+}\right.$ / $\left.\mathrm{SiW}_{12} \mathrm{O}_{40}{ }^{4-}\right\}_{2} /$ ITO, Fig. 3b, and $\left\{\left[\operatorname{NiTPyP}\left(\mathrm{Crphen}_{2} \mathrm{Cl}\right)_{4}\right]^{8+} / \mathrm{SiW}_{12}\right.$ $\left.\mathrm{O}_{40}{ }^{4-}\right\}_{3} / \mathrm{ITO}$, Fig. 3c, is increased. The growth is combined with the coverage, i.e., the surface film formation in other zones where the layer by layer packing of $\mathrm{Ni}(\mathrm{II})$ porphyrin/polyoxometalate takes place.

$\left\{\left[\mathrm{FeTPyP}\left(\mathrm{Crphen}_{2} \mathrm{Cl}\right)_{4}\right]^{8+} / \mathrm{SiW}_{12} \mathrm{O}_{40}{ }^{4-}\right\}_{1} /$ ITO shows a heterogeneous surface, Fig. $3 \mathrm{~d}$, devoid of the aggregates seen in the $\{$ [NiTPyP $\left.\left.\left(\text { Crphen }_{2} \mathrm{Cl}\right)_{4}\right]^{8+} / \mathrm{SiW}_{12} \mathrm{O}_{40}{ }^{4-}\right\}_{1} /$ ITO system. Multilayers $\{[\mathrm{FeTPyP}$ $\left.\left.\left(\text { Crphen }_{2} \mathrm{Cl}\right)_{4}\right]^{8+} / \mathrm{SiW}_{12} \mathrm{O}_{40}{ }^{4-}\right\}_{2} /$ ITO and $\left\{\left[\text { FeTPyP }\left(\text { Crphen }_{2} \mathrm{Cl}\right)_{4}\right]^{8+} /\right.$ $\left.\mathrm{SiW}_{12} \mathrm{O}_{40}{ }^{4-}\right\}_{3} /$ ITO show a higher surface coverage, (see Fig. 3e and 3f) and a more layer by layer packing when they are compared to analogs of Ni porphyrins (see Fig. 3b and 3c).

Consequently, SEM results demonstrate that with depositions $\mathrm{n}_{\mathrm{i}} \geq 2$, a homogeneous multilayer assembly can be obtained. It must be noted that as the number of immersions increase, the morphology of these hybrid systems show a similar pattern.

On the basis of the results presented above, it is concluded than the first deposition does not generate a layer by layer assembly. This can be a consequence of the size of the molecules that are small in comparison to the macromolecules, such as polyelectrolytes, used in the construction of layer by layer assemblies more frequently. Because of the molecules small size, a larger number of depositions is needed to generate a homogeneous layer by layer structure on a surface [24,31].

\subsubsection{Cyclic Voltammetry}

Cyclic voltammetry of the macrocyclic complexes in acetonitrile solution have been described in detail [40]. Figs. 4 and 5 show the cyclic voltammograms of $\left\{\left[\text { FeTPyP }\left(\operatorname{Crphen}_{2} \mathrm{Cl}\right)_{4}\right]^{8+} / \mathrm{SiW}_{12}\right.$ $\left.\mathrm{O}_{40}{ }^{4-}\right\}_{n_{\mathrm{i}}} / \mathrm{GC}$ and $\left\{\left[\operatorname{NiTPyP}\left(\operatorname{Crphen}_{2} \mathrm{Cl}\right)_{4}\right]^{8+} / \mathrm{SiW}_{12} \mathrm{O}_{40}{ }^{4-}\right\}_{\mathrm{n}_{\mathrm{i}}} / \mathrm{GC}$ multilayers onto glassy carbon electrodes respectively.

$\left\{\left[\text { FeTPyP }\left(\operatorname{Crphen}_{2} \mathrm{Cl}\right)_{4}\right]^{8+} / \mathrm{SiW}_{12} \mathrm{O}_{40}{ }^{4-}\right\}_{\mathrm{n}_{\mathrm{i}}} / \mathrm{GC} \quad\left(\mathrm{n}_{\mathrm{i}}=1\right.$ to $\left.\mathrm{n}_{\mathrm{i}}=4\right)$ multilayerspresent two quasireversible processes in $0.1 \mathrm{M} \mathrm{NaClO}_{4}$ solution with a formal potential centered at $\mathrm{E}^{\circ \prime}=+0.34 \mathrm{~V}$ associated with the $\mathrm{Cr}(\mathrm{III}) / \mathrm{Cr}(\mathrm{II})$ couple. The quasireversible process with an $\mathrm{E}^{\circ \prime}=-0.88 \mathrm{~V}$ is associated with a reduction of $\mathrm{SiW}_{12} \mathrm{O}_{40}{ }^{4-}$ in the multilayers. Both anodic and cathodic peak currents of $\mathrm{Cr}(\mathrm{III}) / \mathrm{Cr}(\mathrm{II})$ redox couple, inset Fig. 4, show a linear increment

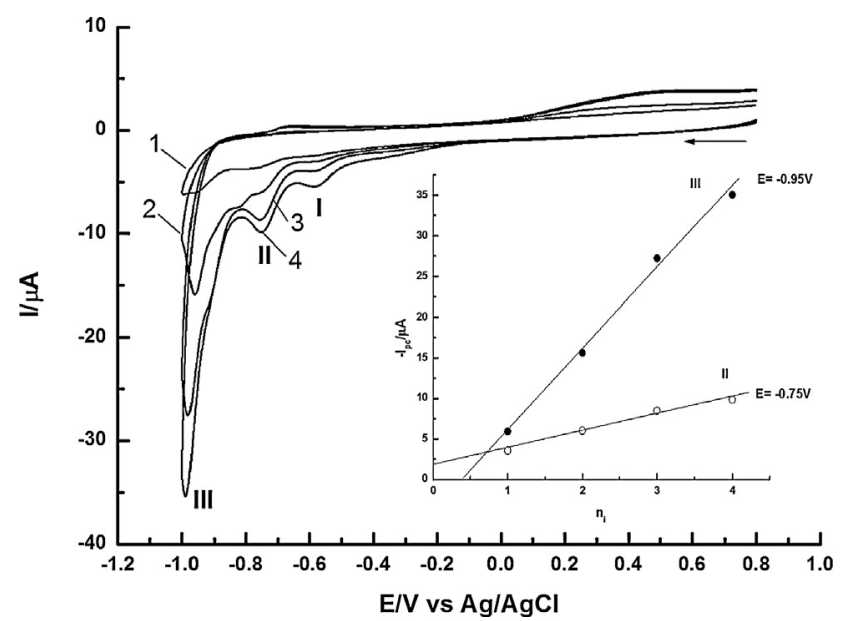

Fig. 5. Cyclic voltammetry of $\left\{\left[\operatorname{NiTPyP}\left(\mathrm{Crphen}_{2} \mathrm{Cl}\right)_{4}\right]^{8+} / \mathrm{SiW}_{12} \mathrm{O}_{40}{ }^{4-}\right\}_{\mathrm{n}_{\mathrm{i}}} / \mathrm{GC}$ multilayers, $\left(n_{i}=1\right.$ to 4$)$. Britton-Robinson solution, $\mathrm{pH}=2$. Scan rate $100 \mathrm{mV} / \mathrm{s}$. Inset: current peak vs Number of immersions for cathodic, process II, III.

with the number of immersions form $n_{i}=1$ to $n_{i}=4$. The linear dependence on $n_{i}$ suggests a correlative aggregation of electroactive species on the electrode. Multilayers with $n_{i} \geq 5$ do not further increase the current, indicating a saturation of the electron transfer rate through multilayers. The electrochemical processes of $\left\{\left[\mathrm{FeTPyP}\left(\mathrm{Crphen}_{2} \mathrm{Cl}\right)_{4}\right]^{8+} / \mathrm{SiW}_{12} \mathrm{O}_{40}{ }^{4-}\right\}_{\mathrm{n}_{\mathrm{i}}} / \mathrm{GC}$ are summarized in eq. 1, 2 according to the respective charges of the voltammetric responses:

Process I/I':

$$
\begin{gathered}
\left\{\left[\text { FeTPyP }\left(\mathrm{Cr}^{\mathrm{III}} \text { phen }_{2} \mathrm{Cl}\right)_{4}\right]^{8+} / \mathrm{SiW}_{12} \mathrm{O}_{40}{ }^{4-}\right\}_{n_{i}} / \mathrm{GC}+4 n e^{-} \\
\rightarrow\left\{\left[\mathrm{FeTPyP}\left(\mathrm{Cr}^{\mathrm{II}} \text { phen }_{2} \mathrm{Cl}\right)_{4}\right]^{4+} / \mathrm{SiW}_{12} \mathrm{O}_{40}{ }^{4-}\right\}_{n_{i}} / G C
\end{gathered}
$$

Process II:

$$
\begin{gathered}
\left\{\left[\text { FeTPyP }\left(\text { CrI }^{I I} \text { phen }_{2} C l\right)_{4}\right]^{4+} / \mathrm{SiW}_{12} \mathrm{O}_{40}{ }^{4-}\right\}_{n_{i}} / G C+1 n e^{-} \\
\rightarrow\left\{\left[\mathrm{FeTPyP}\left(\mathrm{Cr}^{\mathrm{II}} \text { phen }_{2} \mathrm{Cl}\right)_{4}\right]^{4+} / \mathrm{SiW}_{12} \mathrm{O}_{40}{ }^{5-}\right\}_{n_{i}} / G C
\end{gathered}
$$

On the other hand, $\left\{\left[\operatorname{NiTPyP}\left(\operatorname{Crphen}_{2} \mathrm{Cl}\right)_{4}\right]^{8+} / \mathrm{SiW}_{12} \mathrm{O}_{40}{ }^{4-}\right\}_{\mathrm{n}_{\mathrm{i}}} / \mathrm{GC}$, does not show the $\mathrm{Cr}(\mathrm{III}) / \mathrm{Cr}$ (II) couple observed in $\left\{\left[\text { FeTPyP }\left(\text { Crphen }_{2} \mathrm{Cl}\right)_{4}\right]^{8+} / \mathrm{SiW}_{12} \mathrm{O}_{40}{ }^{4-}\right\}_{\mathrm{n}_{\mathrm{i}}} / \mathrm{GC}$ multilayers, Fig. 5. $\left\{\left[\operatorname{NiTPyP}\left(\operatorname{Crphen}_{2} \mathrm{Cl}\right)_{4}\right]^{8+} / \mathrm{SiW}_{12} \mathrm{O}_{40}{ }^{4-}\right\}_{\mathrm{n}_{\mathrm{i}}} / \mathrm{GC}$ undergoes two irreversible redox processes, labeled $\mathrm{I}$ and II with the respective peak potentials $E_{p c}=-0.58 \mathrm{~V}$ and $E_{p c}=-0.75 \mathrm{~V}$. They are attributed to the formation of $\pi$ radicals centered in the TPyP ligand [54], There is a third irreversible reduction of $\left\{\left[\operatorname{NiTPyP}\left(\operatorname{Crphen}_{2} \mathrm{Cl}\right)_{4}\right]^{8+} /\right.$ $\left.\mathrm{SiW}_{12} \mathrm{O}_{40}{ }^{4-}\right\}_{\mathrm{n}_{\mathrm{i}}} / \mathrm{GC}$ multilayers that is labeled III. The charge of III indicates a combination of two process. They have been tentatively associated with the $\mathrm{Ni}(\mathrm{II})$ porphyrin and with the reduction of the polyoxometalate. The inset in Fig. 5 shows that $-\mathrm{I}_{\mathrm{pc}}$ of processes II and III increases with immersions number, $\mathrm{n}_{\mathrm{i}}$, confirming that electroactive species are adsorbed onto the electrode in a layer by layer packing. The electrochemical process of $\left\{\left[\mathrm{NiTPyP}\left(\mathrm{Crphen}_{2} \mathrm{Cl}\right)_{4}\right]^{8+} / \mathrm{SiW}_{12} \mathrm{O}_{40}{ }^{4-}\right\}_{\mathrm{n}_{\mathrm{i}}} / \mathrm{GC}$ multilayers are represented in eqs. 3 - 5 in accordance to the respective charges of voltammetric responses:

Process I:

$$
\begin{gathered}
\left\{\left[\operatorname{NiTPy}_{\left.\left.\left(\text {Crphen }_{2} \mathrm{Cl}\right)_{4}\right]^{8+} / \mathrm{SiW}_{12} \mathrm{O}_{40}{ }^{4-}\right\} n i / G C+n e^{-}}\right.\right. \\
\rightarrow\left\{\left[\operatorname{NiTPyP}\left(\text { Crphen }_{2} \mathrm{Cl}\right)_{4}\right]^{7+} / \mathrm{SiW}_{12} \mathrm{O}_{40}{ }^{4-}\right\} n i / G C
\end{gathered}
$$




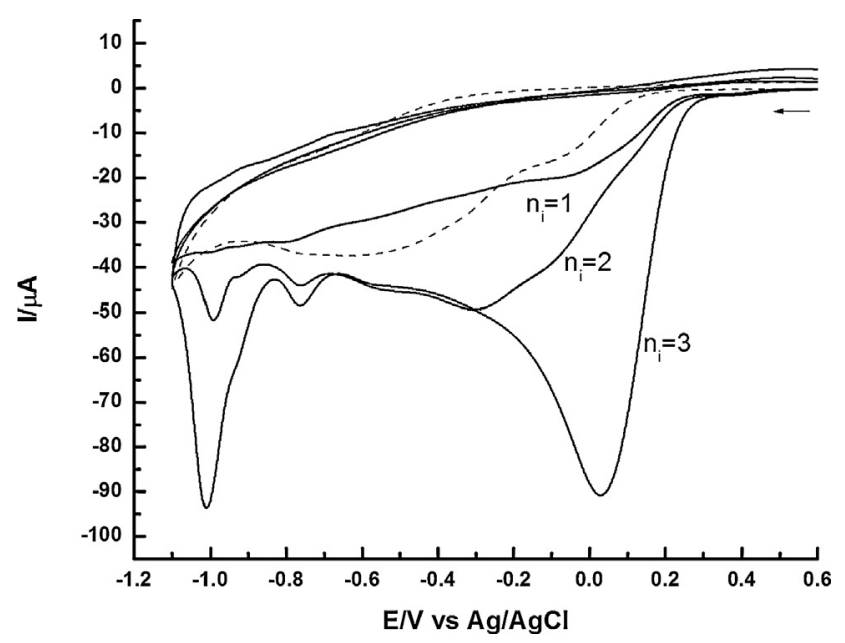

Fig. 6. (Solid line) Cyclic voltammetry of $\left\{\left[\mathrm{FeTPyP}\left(\mathrm{Crphen}_{2} \mathrm{Cl}\right)_{4}\right]^{8+} / \mathrm{SiW}_{12} \mathrm{O}_{40}{ }^{4-}\right\}_{\mathrm{n}_{\mathrm{i}}}$. multilayers, where $\mathrm{n}_{\mathrm{i}}=1$ to 3 , (Dotted line) $\left[\mathrm{FeTPyP}\left(\mathrm{Crphen}_{2} \mathrm{Cl}\right)_{4}\right]^{8+} / \mathrm{GC}$. BrittonRobinson solution saturated with $\mathrm{O}_{2}, \mathrm{pH}=2$. Scan rate $100 \mathrm{mV} / \mathrm{s}$.

Process II:

$$
\begin{gathered}
\left\{\left[\operatorname{NiTPyP}\left(\text { Crphen }_{2} \mathrm{Cl}\right)_{4}\right]^{7+} / \mathrm{SiW}_{12} \mathrm{O}_{40}{ }^{4-}\right\} n i / G C+n e^{-} \\
\rightarrow\left\{\left[\operatorname{NiTPyP}\left(\text { Crphen }_{2} \mathrm{Cl}\right)_{4}\right]^{6+} / \mathrm{SiW}_{12} \mathrm{O}_{40}{ }^{4-}\right\} n i / G C
\end{gathered}
$$

Process III:

$$
\begin{aligned}
& \left\{\left[\operatorname{NiTPyP}\left(\mathrm{Crphen}_{2} \mathrm{Cl}\right)_{4}\right]^{6+} / \mathrm{SiW}_{12} \mathrm{O}_{40}{ }^{4-}\right\} n i / G C+2 n e^{-} \\
& \quad \rightarrow \text { reduced assembly }
\end{aligned}
$$

The apparent surface coverage, $\Gamma_{\text {ap }}=4.5 \times 10^{-9} \mathrm{~mol} / \mathrm{cm}^{2}$, was obtained by integration of the wave associated with the $\mathrm{Cr}$ (III)/ $\mathrm{Cr}$ (II) redox couple in $\left\{\left[\mathrm{FeTPyP}\left(\mathrm{Crphen}_{2} \mathrm{Cl}\right)_{4}\right]^{8+} / \mathrm{SiW}_{12} \mathrm{O}_{40}{ }^{4-}\right\}_{3} / \mathrm{GC}$ (4 electrons). It was also assumed that the first reduction of the $\left\{\left[\operatorname{NiTPyP}\left(\operatorname{Crphen}_{2} \mathrm{Cl}\right)_{4}\right]^{8+} / \mathrm{SiW}_{12} \mathrm{O}_{40}{ }^{4-}\right\}_{2} / \mathrm{GC}$ assemblage under $\mathrm{N}_{2}$ atmosphere was a monoelectronic process [55-64]. The integration yield an apparent surface coverage, $\Gamma_{\mathrm{ap}}=3.85 \times 10^{-7} \mathrm{~mol} / \mathrm{cm}^{2}$. Using $2.2 \mathrm{~nm}$ as the ratio of the porphyrin[64,65], it was determined that a monolayer of adsorbed porphyrin corresponds to $1.1 \times 10^{-11} \mathrm{~mol} / \mathrm{cm}^{2}$. Therefore the apparent values of surface coverage suggest that the porphyrins are ordered in multilayers on the surface of the glassy carbon electrode. The values of $\Gamma_{\text {ap }}$ were used for the interpretation of the rotating disk experiments discussed below.

It must be noted that quite similar voltammetric responses were observed despite whether the multilayers were adsorbed on ITO or glassy carbon electrodes, either under $\mathrm{N}_{2}$ or $\mathrm{O}_{2}$ atmosphere (section 3.2). However glassy carbon electrode was preferred because carbon is a more common material for application in energy studies.

\subsection{Electrocatalytic studies in $\mathrm{O}_{2}$ reduction with multilayers} assemblies of $\left\{\left[\text { FeTPyP }\left(\text { Crphen }_{2} \mathrm{Cl}\right)_{4}\right]^{8+} / \mathrm{SiW}_{12} \mathrm{O}_{40}{ }^{4-}\right\}_{n_{i}} /$ GC and $\left\{\left[\operatorname{NiTPy}\left(\text { Crphen }_{2} \mathrm{Cl}\right)_{4}\right]^{8+} / \mathrm{SiW}_{12} \mathrm{O}_{40}{ }^{4-}\right\}_{n_{i}} / G C$.

Fig. 6 shows the cyclic voltammogram of multilayer assemblies of $\left\{\left[\mathrm{FeTPyP}\left(\mathrm{Crphen}_{2} \mathrm{Cl}\right)_{4}\right]^{8+} / \mathrm{SiW}_{12} \mathrm{O}_{40}{ }^{4-}\right\}_{\mathrm{n}_{\mathrm{i}}} / \mathrm{GC}\left(\mathrm{n}_{\mathrm{i}}=1-3\right)$ in aqueous oxygen saturated solutions compared to [FeTPyP $\left.\left(\text { Crphen }_{2} \mathrm{Cl}\right)_{4}\right]^{8+} / \mathrm{GC}$ modified electrode. A higher number of multilayers does not show better activity than $n_{i}=3$. Cyclic voltammograms were recorded at $100 \mathrm{mV} / \mathrm{s}$ scan rate. Between 0.2 and $-0.2 \mathrm{~V}$ a notorious increase in the cathodic current is observed, corresponding to the oxygen reduction. Oxygen reduction shifts

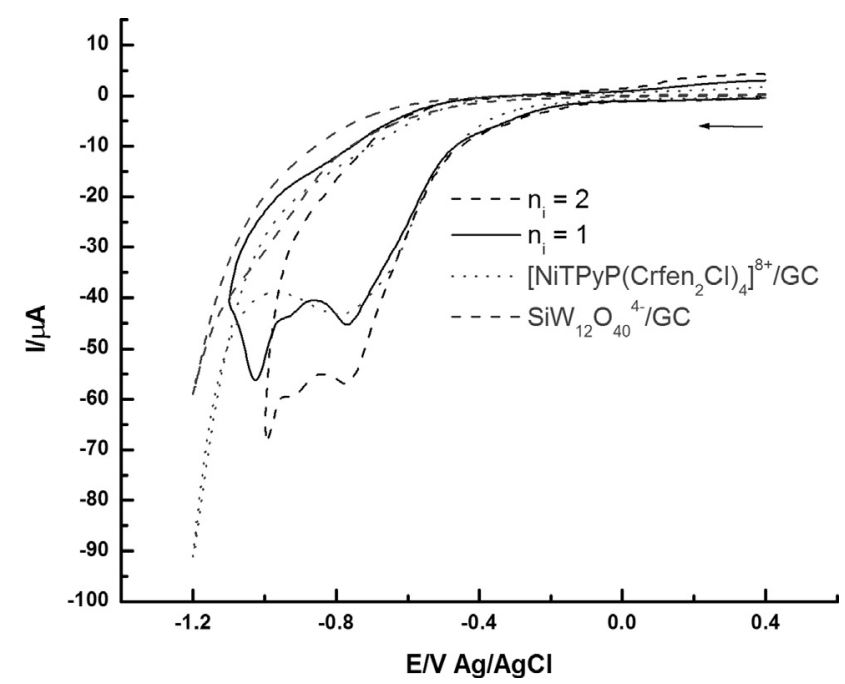

Fig. 7. Cyclic voltammetry of $\left\{\left[\operatorname{NiTPyP}\left(\operatorname{Crphen}_{2} \mathrm{Cl}\right)_{4}\right]^{8+} / \mathrm{SiW}_{12} \mathrm{O}_{40}{ }^{4-}\right\}_{\mathrm{n}_{\mathrm{i}}} / \mathrm{GC}$ multilayer $n_{i}=2$ (black line), $n_{i}=1$ (red line), $\left[\operatorname{NiTPyP}\left(\operatorname{Crphen}_{2} \mathrm{Cl}\right)_{4}\right]^{8+} / G C$ (blue line), $\mathrm{SiW}_{12} \mathrm{O}_{40}{ }^{4-} / \mathrm{GC}$ (green line). Britton-Robinson solution saturated with $\mathrm{O}_{2}, \mathrm{pH}=2$. Scan rate $100 \mathrm{mV} / \mathrm{s}$.

to more positive potentials with $n_{i}$, ranging from $\sim+0.04 \mathrm{~V}$ when $\mathrm{n}_{\mathrm{i}}=1$ to $+0.22 \mathrm{~V}$ when $\mathrm{n}_{\mathrm{i}}=3$. This experimental observation shows that electrocatalytic effect improves when the deposition number increases. Moreover, the current increase between [FeTPyP $\left.\left(\text { Crphen }_{2} \mathrm{Cl}\right)_{4}\right]^{8+} / \mathrm{GC}$ and $\left\{\left[\mathrm{FeTPyP}\left(\text { Crphen }_{2} \mathrm{Cl}\right)_{4}\right]^{8+} / \mathrm{SiW}_{12} \mathrm{O}_{40}{ }^{4-}\right\}_{\mathrm{n}_{\mathrm{i}}} /$ $\mathrm{GC}$ is 11.6 times. Additionally, two irreversible waves at $-0.78 \mathrm{~V}$ and $-1.10 \mathrm{~V}$ are observed in the cyclic voltammograms, probably associated with proton reduction or inner processes of the assemblies.

Cyclic voltammograms recorded in the presence of $1 \mathrm{mM} \mathrm{H}_{2} \mathrm{O}_{2}$ exhibited a similar dependence on the multilayer number, Figure $\mathrm{S} 4$. The multilayer assemblies can reduce hydrogen peroxide at the same potentials where oxygen is reduced, i. e., at $+0.07 \mathrm{~V}$, $-0.55 \mathrm{~V}$ and $-0.74 \mathrm{~V}$. It must concluded that the multilayers assemblies $\left\{\left[\text { FeTPyP }\left(\text { Crphen }_{2} \mathrm{Cl}\right)_{4}\right]^{8+} / \mathrm{SiW}_{12} \mathrm{O}_{40}{ }^{4-}\right\}_{\mathrm{n}_{\mathrm{i}}} / \mathrm{GC}$ reduce oxygen to water in a process where $\mathrm{H}_{2} \mathrm{O}_{2}$ is a reaction intermediate. This kind of mechanism is described as $\left[2 \mathrm{e}^{-}+2 \mathrm{e}^{-}\right][66]$.

The cyclic voltammograms of $\left\{\left[\operatorname{NiTPyP}\left(\operatorname{Crphen}_{2} \mathrm{Cl}\right)_{4}\right]^{8+} / \mathrm{SiW}_{12}\right.$ $\left.\mathrm{O}_{40}{ }^{4-}\right\}_{\mathrm{n}_{\mathrm{i}}} / \mathrm{GC}(\mathrm{n}=1,2)$ multilayers in $\mathrm{O}_{2}$ saturated solution are shown in Fig. 7. A higher number of multilayers does not show better activity than $n_{i}=2$. Two irreversible waves are observed at $0.79 \mathrm{~V}$ and $-1.0 \mathrm{~V}$. The $\left\{\left[\operatorname{NiTPyP}\left(\mathrm{Crphen}_{2} \mathrm{Cl}\right)_{4}\right]^{8+} / \mathrm{SiW}_{12} \mathrm{O}_{40}{ }^{4-}\right\}_{1} / \mathrm{GC}$ assembly and the corresponding control $\mathrm{Ni}$ porphyrin [NiTPyP $\left(\text { Crphen }{ }_{2} \mathrm{Cl}_{4}\right]^{8+} / \mathrm{GC}$ are equally poor electrocataysts (similar currents were recorded for the oxygen reduction). In an analogous experiment, the multilayer $\left\{\left[\operatorname{NiTPyP}\left(\mathrm{Crphen}_{2} \mathrm{Cl}\right)_{4}\right]^{8+} / \mathrm{SiW}_{12}\right.$ $\left.\mathrm{O}_{40}{ }^{4-}\right\}_{2} / \mathrm{GC}$ produced a current at $-0.79 \mathrm{~V}$ that is 1.17 times larger than the layer $\left[\mathrm{NiTPyP}\left(\mathrm{Crphen}_{2} \mathrm{Cl}\right)_{4}\right]^{8+} / \mathrm{GC}$ control showing therefore a small electrocatalytic activity in the $\mathrm{O}_{2}$ reduction. Solutions containing $1 \mathrm{mM} \mathrm{H}_{2} \mathrm{O}_{2}$ were also used for a study of the multilayers electrocatalytic activity, Figure S5. The multilayer with $\mathrm{n}_{\mathrm{i}}=2$ showed electrocatalytic activity. Cyclic voltammograms of the $\left\{\left[\mathrm{NiTPyP}\left(\operatorname{Crphen}_{2} \mathrm{Cl}\right)_{4}\right]^{8+} / \mathrm{SiW}_{12} \mathrm{O}_{40}{ }^{4-}\right\}_{\mathrm{n}_{\mathrm{i}}} / \mathrm{GC}$ in the presence of $\mathrm{H}_{2} \mathrm{O}_{2}$ exhibit three different cathodic process at $-0.58 \mathrm{~V},-0.76 \mathrm{~V}$ and $-0.97 \mathrm{~V}$. The observed voltammetric currents at $-0.76 \mathrm{~V}$ are 3 times larger than the one recorded with the $\left[\operatorname{NiTPyP}\left(\operatorname{Crphen}_{2} \mathrm{Cl}\right)_{4}\right]^{8+} / \mathrm{GC}$ blank. In spite of the apparent low electrocatalytic activity in the $\mathrm{O}_{2}$ reduction, the multilayer assemblies are able to reduce $\mathrm{H}_{2} \mathrm{O}_{2}$. Therefore, is reasonable that $\left\{\left[\operatorname{NiTPyP}\left(\operatorname{Crphen}_{2} \mathrm{Cl}\right)_{4}\right]^{8+} /\right.$ $\left.\mathrm{SiW}_{12} \mathrm{O}_{40}{ }^{4-}\right\}_{\mathrm{n}_{\mathrm{i}}} / \mathrm{GC}$ reduce oxygen by a $\left[2 \mathrm{e}^{-}+2 \mathrm{e}^{-}\right]$mechanism.

This pattern has been discussed before by Drain et al. [24], where multilayer hybrids based in porphyrins/polyoxometalate showed 


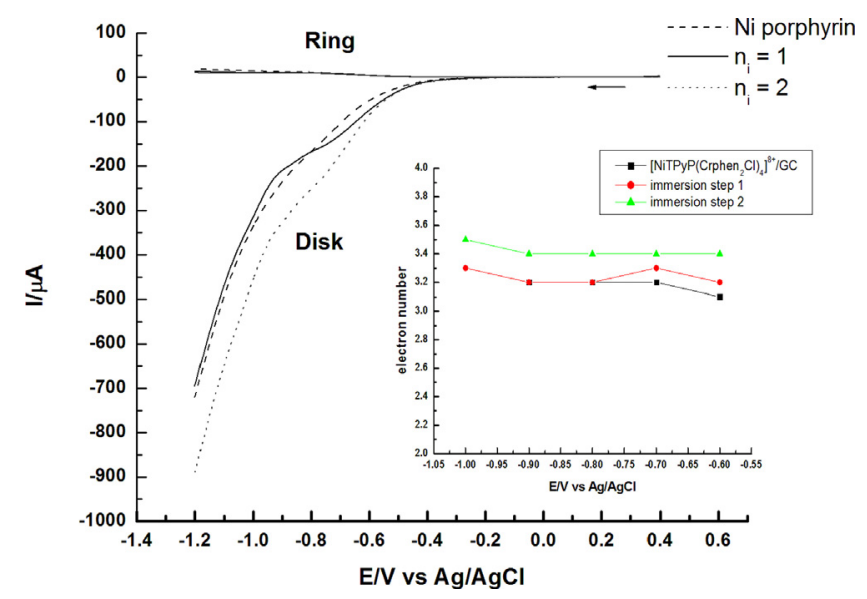

Fig. 8. Linear Swept voltammetry of $\left\{\left[\operatorname{NiTPyP}\left(\operatorname{Crphen}_{2} \mathrm{Cl}\right)_{4}\right]^{8+} / \mathrm{SiW}_{12} \mathrm{O}_{40}{ }^{4-}\right\}_{\mathrm{n}_{\mathrm{i}}} / \mathrm{GC}$ multilayer, $\mathrm{n}_{\mathrm{i}}=1$ (dotted line), $\mathrm{n}_{\mathrm{i}}=2$ (continues line) and $\left[\mathrm{NiTPyP}\left(\mathrm{Crphen}_{2} \mathrm{Cl}\right)_{4}\right]^{8+} / \mathrm{GC}$ (dashed line) onto RRDE in $\mathrm{O}_{2}$ saturated. Rotation rate $250 \mathrm{rpm}$. Britton-Robinson solution at $\mathrm{pH}=2$. Scan rate $5 \mathrm{mV} / \mathrm{s}$. Pt ring potential set at $+1.2 \mathrm{~V}$. Inset: electron number vs potential.

an increase in its electrocatalytic properties accordingly to the immersion steps, because the synergic effects explained before.

Besides, $\mathrm{SiW}_{12} \mathrm{O}_{40}{ }^{4-} / \mathrm{GC}$ modified electrode showed no electrocatalytic activity towards the reaction under survey in a $\mathrm{O}_{2}$ saturated solution and buffered at $\mathrm{pH}=2$, Figure $\mathrm{S} 3$. In contrast to this inactivity shown in the $\mathrm{O}_{2}$ reduction, $\mathrm{SiW}_{12} \mathrm{O}_{40}{ }^{4-} / \mathrm{GC}$ reduced $\mathrm{H}_{2} \mathrm{O}_{2}$ at potentials near to those where electrostatic multilayer assemblies reduce hydrogen peroxide. This experimental observation suggests that the $\mathrm{SiW}_{12} \mathrm{O}_{4}{ }^{4-}$ is involved in the $\mathrm{H}_{2} \mathrm{O}_{2}$ reduction at potentials more negative than $-0.6 \mathrm{~V}$.

\subsubsection{Rotating ring-disk electrode, RRDE studies.}

RRDE technique has been applied to the elucidation of the oxygen reduction mechanisms on different modified electrodes, including adsorbed porphyrins, membranes and conducting polymers $[11,45,47,55,56,58,63,67-71]$. A feature of these RRDE techniques is that the reproducibility of the measurement is dependent on the constant ratio of the ring/disk current.

In our experiments, the electrochemical oxygen reduction was investigated scanning the disk potential between $+0.4 \mathrm{~V}$ and $-1.2 \mathrm{~V}$, and applying $\mathrm{a}+1.2 \mathrm{~V}$ constant potential at the ring. The rotation speed was fixed at 250 r.p.m to avoid turbulent regime for all multilayers systems [72].

Fig. 8 shows the corresponding pseudo-polarization curves for the oxygen reduction on a glassy carbon disk $\left\{\left[\operatorname{NiTPyP}\left(\mathrm{Crphen}_{2} \mathrm{Cl}\right)_{4}\right]^{8+} / \mathrm{SiW}_{12} \mathrm{O}_{40}{ }^{4-}\right\}_{\mathrm{n}_{\mathrm{i}}} / \mathrm{GC}$ electrode modified and $\left[\operatorname{NiTPyP}\left(\operatorname{Crphen}_{2} \mathrm{Cl}\right)_{4}\right]^{8+} / \mathrm{GC}$. It is observed a reduced diffusion process for the oxygen reduction, starting at $-0.5 \mathrm{~V}$, a potential close to the one recorded with the electrode modified with [NiTPyP $\left.\left(\text { Crphen }{ }_{2} \mathrm{Cl}\right)_{4}\right]^{8+} / \mathrm{GC}$.

For $\left[\mathrm{NiTPyP}\left(\mathrm{Crphen}_{2} \mathrm{Cl}\right)_{4}\right]^{8+} / \mathrm{GC}$, at the ring, an oxidation process is observed on the ring electrode at the same potential where the reduction process was registered. It shows that $\mathrm{H}_{2} \mathrm{O}_{2}$, formed as a reaction intermediate is oxidized, at the ring electrode. The $\mathrm{i}_{\text {ring }} / \mathrm{i}_{\text {disk }}$ ratio is almost constant and varies between $0.01 \sim 0.08$ in these polarization curves, indicating that a regime of laminar-flow is taking place $[11,45,47,63,67-72]$.

The number of electrons $(n)$ and the amount of $\mathrm{H}_{2} \mathrm{O}_{2}[72,73]$ can be obtained employing eq. 6, 7. Electrochemical data for all multilayers described in this work are presented in Table I.

$$
\begin{aligned}
& n=4 I_{d} /\left(I_{d}+I_{r} / N\right) \\
& \% H_{2} O_{2}=100\left(2 I_{r} / N\right) /\left(I_{d}+I_{r} / N\right)
\end{aligned}
$$

Table 1

RRDE parameters at different potentials: a) $-0.80 \mathrm{~V}, \mathrm{~b})-0.23 \mathrm{~V}, \mathrm{c})-0.90 \mathrm{~V}, \mathrm{~d})-0.10 \mathrm{~V}$.

\begin{tabular}{|c|c|c|}
\hline System & $\mathrm{n}$ & $\% \mathrm{H}_{2} \mathrm{O}_{2}$ \\
\hline$\left[\operatorname{NiTPyP}\left(\text { Crphen }_{2} \mathrm{Cl}\right)_{4}\right]\left[\mathrm{PF}_{6}\right]_{8}$ & $3.2^{\mathrm{a}}$ & $38.4^{\mathrm{a}}$ \\
\hline$\left[\operatorname{NiTPyP}\left(\text { Crphen }_{2} \mathrm{Cl}\right)_{4}\right]^{8+} / \mathrm{SiW}_{12} \mathrm{O}_{40}{ }^{4-}$ & $3.2^{\mathrm{a} / 3.4^{\mathrm{c}}}$ & $41.9^{\text {a }} 33.7^{c}$ \\
\hline 2 bilayer & $3.5^{c}$ & $28.3^{c}$ \\
\hline$\left[\mathrm{FeTPyP}\left(\mathrm{Crphen}_{2} \mathrm{Cl}\right)_{2}\right]\left[\mathrm{PF}_{6}\right]_{8}$ & $2.7^{\mathrm{a} / 2.6^{\mathrm{b}}}$ & $62^{\mathrm{a} / 72.7^{\mathrm{b}}}$ \\
\hline$\left[\text { FeTPyP }\left(\text { Crphen }_{2} \mathrm{Cl}\right)_{4}\right]^{8+} / \mathrm{SiW}_{12} \mathrm{O}_{40}{ }^{4-}$ & $3.0^{\mathrm{d}} / 3.1^{\mathrm{e}}$ & $50.5^{\mathrm{d}} 45.4^{\mathrm{e}}$ \\
\hline 2 bilayer & $3.4^{\mathrm{d} / 3.5^{\mathrm{e}}}$ & $28.1^{\mathrm{d}} 24.9^{\mathrm{e}}$ \\
\hline 3 bilayer & $3.6^{\mathrm{d}} / 3.5^{\mathrm{e}}$ & $18.6^{\mathrm{d}} 24.7^{\mathrm{e}}$ \\
\hline
\end{tabular}
a) $-0.1 \mathrm{~V}$; b) $-0.23 \mathrm{~V}$; c) $-0.8 \mathrm{~V}$; d) $-0.9 \mathrm{~V}$.

Where $n=$ total electron transferred, and $\% \mathrm{H}_{2} \mathrm{O}_{2}$ is the yield of hydrogen peroxide oxidized at the ring.

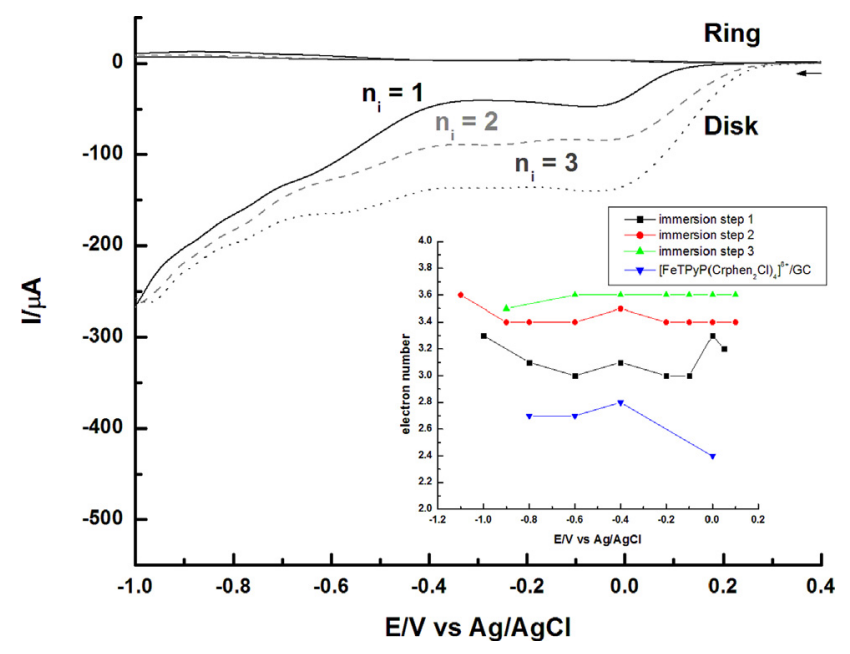

Fig. 9. Linear swept voltammetry $\left\{\left[\mathrm{FeTPyP}\left(\operatorname{Crphen}_{2} \mathrm{Cl}\right)_{4}\right]^{8+} / \mathrm{SiW}_{12} \mathrm{O}_{40}{ }^{4-}\right\}_{\mathrm{n}_{\mathrm{i}}} / \mathrm{GC}$ onto rotating-ring disk electrode in saturated $\mathrm{O}_{2}$ aqueous solution. Rotation rate $250 \mathrm{rpm}$. Britton-Robinson solution at $\mathrm{pH}=2$. Scan rate $5 \mathrm{mV} / \mathrm{s}$. Pt ring potential set at $1.2 \mathrm{~V}$. Inset: electron number vs potential.

Identical number of electrons were respectively calculated withthe $\left\{\left[\operatorname{NiTPyP}\left(\mathrm{Crphen}_{2} \mathrm{Cl}\right)_{4}\right]^{8+} / \mathrm{SiW}_{12} \mathrm{O}_{40}{ }^{4-}\right\}_{1} / \mathrm{GC}$ multilayer and $\left[\operatorname{NiTPyP}\left(\operatorname{Crphen}_{2} \mathrm{Cl}\right)_{4}\right]^{8+} / \mathrm{GC}$ at modified electrodes at the same potential, inset in Fig. 8 and Table 1. However, a small increase in the calculated electron number and a decrease in the amount of $\mathrm{H}_{2} \mathrm{O}_{2}$ oxidized was obtained with the $\left\{\left[\operatorname{NiTPyP}\left(\operatorname{Crphen}_{2} \mathrm{Cl}\right)_{4}\right]^{8+} / \mathrm{SiW}_{12}\right.$ $\left.\mathrm{O}_{40}{ }^{4-}\right\}_{2} / \mathrm{GC}$ multilayer, Table 1 . These results suggest that a $\left[2 \mathrm{e}^{-}+2 \mathrm{e}^{-}\right]$mechanism is taking place when [NiTPyP $\left.\left(\mathrm{Crphen}_{2} \mathrm{Cl}\right)_{4}\right]^{8+} / \mathrm{GC}$ modified electrode reduces oxygen at $-0.80 \mathrm{~V}$. Also, the yield of $\mathrm{H}_{2} \mathrm{O}_{2}$ decrease from $\left\{\left[\operatorname{NiTPyP}\left(\mathrm{Crphen}_{2} \mathrm{Cl}\right)_{4}\right]^{8+}\right.$ / $\left.\mathrm{SiW}_{12} \mathrm{O}_{40}{ }^{4-}\right\}_{1} / \mathrm{GC}$ and $\left\{\left[\mathrm{NiTPyP}\left(\mathrm{Crphen}_{2} \mathrm{Cl}\right)_{4}\right]^{8+} / \mathrm{SiW}_{12} \mathrm{O}_{40}{ }^{4-}\right\}_{2} / \mathrm{GC}$ multilayer assembly from $34 \%$ to $28 \%$. $\left\{\left[\operatorname{NiTPyP}\left(\mathrm{Crphen}_{2} \mathrm{Cl}\right)_{4}\right]^{8+} /\right.$ $\left.\mathrm{SiW}_{12} \mathrm{O}_{40}{ }^{4-}\right\}_{2} / \mathrm{GC}$ assembly favored slightly a four direct electron reduction. Nevertheless a $\left[2 \mathrm{e}^{-}+2 \mathrm{e}^{-}\right]$mechanism is predominantly in all the $\mathrm{Ni}(\mathrm{II})$ assemblages.

In addition, Fig. 9 shows pseudo-polarization curves of $\left\{\left[\text { FeTPyP }\left(\text { Crphen }_{2} \mathrm{Cl}\right)_{4}\right]^{8+} / \mathrm{SiW}_{12} \mathrm{O}_{40}{ }^{4-}\right\}_{\mathrm{n}_{\mathrm{i}}} /$ GC multilayers where $\mathrm{n}$ varied from 1 to 3 .

It is seen that at the ring electrode, an oxidation process takes place at the same potential where a reduction process is observed in the disk for each multilayer assembly. The $\mathrm{i}_{\text {ring }} / \mathrm{i}_{\text {disk }}$ ratio calculated is almost constant and varies between 0.01 0.09 in all the polarization curves in Fig. 9, indicating that a regime of laminar-flow is taking place $[11,45,47,63,67-72]$.

Oxygen reduction by $\left\{\left[\mathrm{FeTPyP}\left(\mathrm{Crphen}_{2} \mathrm{Cl}\right)_{4}\right]^{8+} / \mathrm{SiW}_{12} \mathrm{O}_{40}{ }^{4-}\right\}_{1} /$ GC disk begins at $+0.12 \mathrm{~V}$, while $\left\{\left[\text { FeTPyP }\left(\operatorname{Crphen}_{2} \mathrm{Cl}\right)_{4}\right]^{8+} /\right.$ $\left.\mathrm{SiW}_{12} \mathrm{O}_{40}{ }^{4-}\right\}_{2} / \mathrm{GC}$ and $\left\{\left[\text { FeTPyP }\left(\operatorname{Crphen}_{2} \mathrm{Cl}\right)_{4}\right]^{8+} / \mathrm{SiW}_{12} \mathrm{O}_{40}{ }^{4-}\right\}_{3} / G C$ reduces oxygen initially at $+0.2 \mathrm{~V}$, confirming the cyclic voltammetry pattern observed, where a more electrocatalytic system is obtained by increasing the number of deposition from 1 to 3 . 


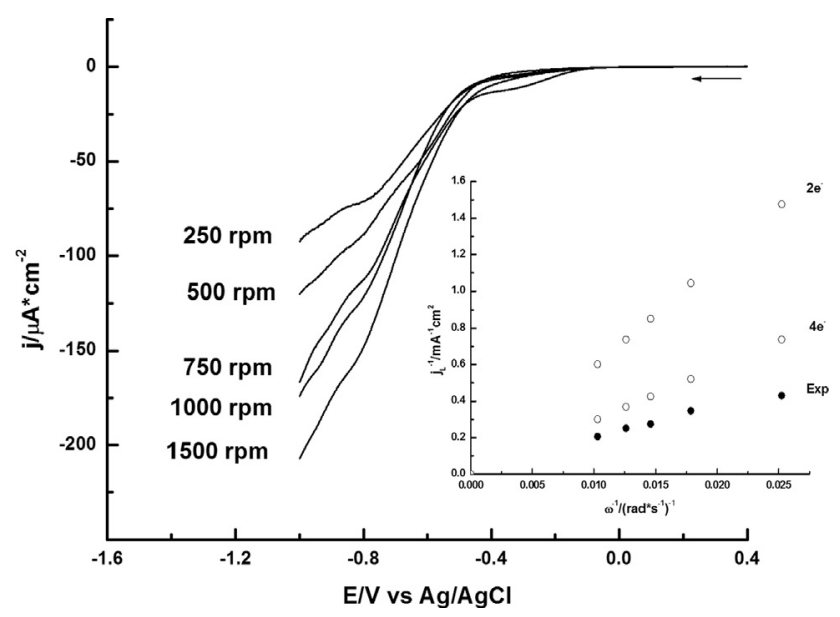

Fig. 10. Polarization curve of $\left\{\left[\mathrm{NiTPyP}\left(\mathrm{Crphen}_{2} \mathrm{Cl}\right)_{4}\right]^{8+} / \mathrm{SiW}_{12} \mathrm{O}_{40}{ }^{4-}\right\}_{2}$ in solution saturated with oxygen, $\mathrm{pH}=2$, at different rotating velocities. Scan rate: $5 \mathrm{mV} / \mathrm{s}$. Inset: Koutecky-Levich curves for multilayers of $\left\{\right.$ NiTPyP $\left.\left(\mathrm{Crphen}_{2} \mathrm{Cl}\right)_{4}\right] /$ $\left.\mathrm{SiW}_{12} \mathrm{O}_{40}{ }^{4-}\right\}_{2} . \Gamma=3.85 \times 10^{-7} \mathrm{~mol} / \mathrm{cm}^{2}$. BR solution $\mathrm{pH}=2$ saturated with $\mathrm{O}_{2}$.

A diffusion process was observed between $\sim 0.0 \mathrm{~V}$ and $-0.4 \mathrm{~V}$ with all the $\left\{\left[\mathrm{FeTPyP}\left(\operatorname{Crphen}_{2} \mathrm{Cl}\right)_{4}\right]^{8+} / \mathrm{SiW}_{12} \mathrm{O}_{40}{ }^{4-}\right\}_{\mathrm{n}} / \mathrm{GC}$ multilayers, Fig. 9. Within the same potential range, an oxidation process is observed with the ring electrode.

The inset to Fig. 9 shows that, compared to the blank [FeTPyP $\left(\text { Crphen }{ }_{2} \mathrm{Cl}_{4}\right]^{8+} / \mathrm{GC}$, the electron number increased from 2.7 for the blank to 3.6 for $\left\{\left[\mathrm{FeTPyP}\left(\operatorname{Crphen}_{2} \mathrm{Cl}_{4}\right]^{8+} / \mathrm{SiW}_{12} \mathrm{O}_{40}{ }^{4-}\right\}_{3} / \mathrm{GC}\right.$ modified electrode at $-0.1 \mathrm{~V}$. In parallel, the yield of $\mathrm{H}_{2} \mathrm{O}_{2}$ decreases notoriously when the electrode is modified with electrostatically assembled multilayers. A change from $62 \%$ to $18.6 \%$ resulted when the $\left[\mathrm{FeTPyP}\left(\mathrm{Crphen}_{2} \mathrm{Cl}\right)_{4}\right]^{8+} / \mathrm{GC}$ control and the multilayer $\left\{\left[\mathrm{FeTPyP}\left(\mathrm{Crphen}_{2} \mathrm{Cl}\right)_{4}\right]^{8+} / \mathrm{SiW}_{12} \mathrm{O}_{40}{ }^{4-}\right\}_{3} / \mathrm{GC}$ were used respectively.

These results show the increase number of multilayers favored a direct four electron mechanism, since the yield $\mathrm{H}_{2} \mathrm{O}_{2}$ ring oxidation decrease drastically when $\left\{\left[\text { FeTPyP }\left(\operatorname{Crphen}_{2} \mathrm{Cl}\right)_{4}\right]^{8+} /\right.$ $\left.\mathrm{SiW}_{12} \mathrm{O}_{40}{ }^{4-}\right\}_{3} / \mathrm{GC}$ was used. Evidencing again the existence of a synergism between cationic porphyrin $\left[\mathrm{FeTPyP}\left(\mathrm{Crphen}_{2} \mathrm{Cl}\right)_{4}\right]^{8+}$ and $\mathrm{SiW}_{12} \mathrm{O}_{40}{ }^{4-}$.

\subsubsection{Rotating disk electrode}

The number of electrons involved in the electrochemical processes studied in this work was calculated through Koutecky-Levich methodology. Currents were measured at $-0.9 \mathrm{~V}$ with $\left\{\left[\operatorname{NiTPyP}\left(\operatorname{Crphen}_{2} \mathrm{Cl}\right)_{4}\right]^{8+} / \mathrm{SiW}_{12} \mathrm{O}_{40}{ }^{4-}\right\}_{2} / \mathrm{GC}$ and at -0.25 with the $\left\{\left[\text { FeTPyP }\left(\text { Crphen }_{2} \mathrm{Cl}\right)_{4}\right]^{8+} / \mathrm{SiW}_{12} \mathrm{O}_{40}{ }^{4-}\right\}_{3} / \mathrm{GC}$ multilayers, It was assumed that only mass transfer processes are effective at these potentials, Figs. 10 and 11. The Koutecky-Levich equations 8 - 10 were used for data treatment.

$1 / i_{\lim }=1 / i_{k 1}+1 / i_{\text {lev }}$

$i_{k 1}=n F A k_{1} C_{O} \Gamma_{a p}$

$i_{\text {lev }}=0.62 n F A C_{O} D^{2 / 3} v^{-1 / 6} \omega^{1 / 2}$

In eqs. 9 and $10, \mathrm{n}$ is the electron number transferred, $\mathrm{F}$ is the Faraday Constant $(96486 \mathrm{Cb} / \mathrm{molK}), \mathrm{D}$ is the coefficient diffusion $1.67 \times 10^{-5} \mathrm{~cm} / \mathrm{s}, \mathrm{C}_{\mathrm{O}}$ is the concentration of $\mathrm{O}_{2}$ under saturated conditions at $\mathrm{pH}=2\left(1.3 \times 10^{-6} \mathrm{~mol} / \mathrm{cm}^{3}\right), v$ is the kinematic viscosity of water $\left(0.01 \mathrm{~cm}^{2} / \mathrm{s}\right), A$ is the area of the electrode $\left(0.071 \mathrm{~cm}^{2}\right), \mathrm{k}_{1}$ is a second order constant for the reaction of $\mathrm{O}_{2}$ with the catalyst and $\Gamma_{\text {ap }}$ is the surface coverage of catalyst $\left(\mathrm{mol} / \mathrm{cm}^{2}\right)[59,72]$.

The slope of the Koutecky-Levich plot for the oxygen reduction over the $\left\{\left[\operatorname{NiTPyP}\left(\operatorname{Crphen}_{2} \mathrm{Cl}\right)_{4}\right]^{8+} / \mathrm{SiW}_{12} \mathrm{O}_{40}{ }^{4-}\right\}_{2} / \mathrm{GC}$ multilayer, inset Fig. 10, has the same value of the slope calculated with

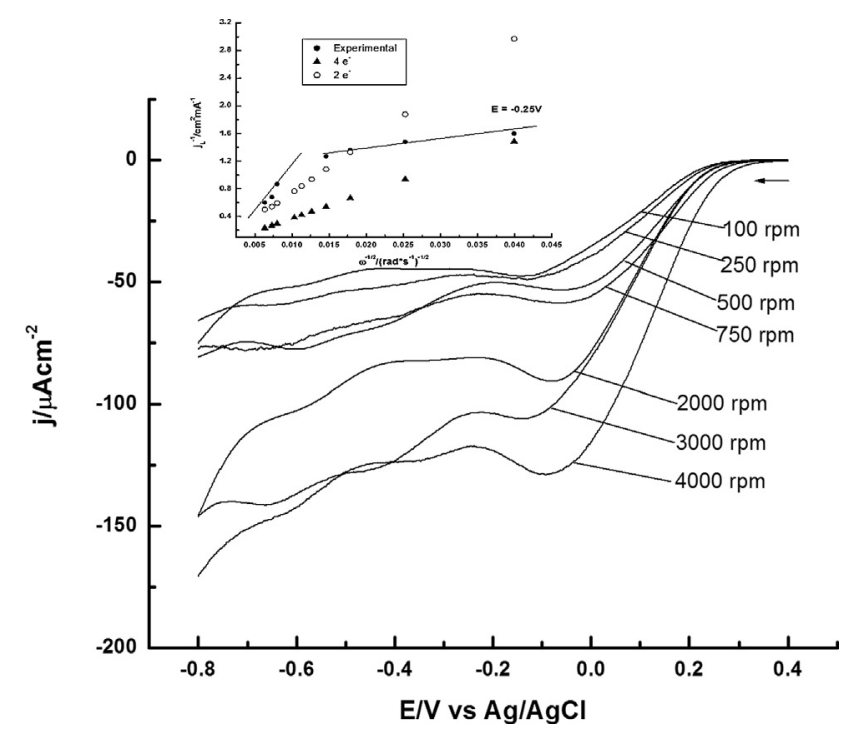

Fig. 11. Polarization curve of $\left\{\left[\mathrm{FeTPyP}\left(\mathrm{Crphen}_{2} \mathrm{Cl}\right)_{4}\right]^{8+} / \mathrm{SiW}_{12} \mathrm{O}_{40}{ }^{4-}\right\}_{3} / \mathrm{GC}$ in solution saturated with oxygen, $\mathrm{pH}=2$, at different rotating velocities. Scan rate: $5 \mathrm{mV} / \mathrm{s}$. Inset: Koutechy-Levichcurve multilayers of $\left.\left\{\left[\mathrm{FeTPyPCrphen}{ }_{2} \mathrm{Cl}\right)_{4}\right]^{+8} / \mathrm{SiW}_{12} \mathrm{O}_{40}{ }^{4-}\right\}_{3}$, $\Gamma=4.5 \times 10^{-9} \mathrm{~mol} / \mathrm{cm}^{2}$. B.R solution $\mathrm{pH}=2$, saturated with $\mathrm{O}_{2}$.

the Koutecky-Levich equations $10-12$. This observation is consistent with an oxygen reduction via four electrons. Moreover, the second order constant $\left(\mathrm{k}_{1}=1.26 \times 10^{6} \mathrm{M}^{-1} \mathrm{~s}^{-1}\right)$ for the formation of the adduct between $\left\{\left[\mathrm{NiTPyP}\left(\mathrm{Crphen}_{2} \mathrm{Cl}\right)_{4}\right]^{8+} / \mathrm{SiW}_{12} \mathrm{O}_{40}{ }^{4-}\right\}_{2} / \mathrm{GC}$ and oxygen was calculated from the intercept of the curve, inset to Fig. 10, using eq. 12.

The Tafel slope calculated for the $\left\{\left[\operatorname{NiTPyP}\left(\operatorname{Crphen}_{2} \mathrm{Cl}\right)_{4}\right]^{8+} /\right.$ $\left.\mathrm{SiW}_{12} \mathrm{O}_{40}{ }^{4-}\right\}_{2} / \mathrm{GC}$ multilayer in the presence of $\mathrm{O}_{2}$ at low polarization zones, between $-0.55 \mathrm{~V}$ and $-0.65 \mathrm{~V}$, has a high value of $0.270 \mathrm{~V} / \mathrm{dec}$. In literature reports, high values of the slope have been associated with a CE process, where the chemical reaction is the rate determining step [74]. On the basis of eq. 11, the standard heterogeneous rate constant obtained from the intercept of the same Tafel plot has an average value of $3.34 \times 10^{-5} \mathrm{~cm} / \mathrm{s}$.

$\ln |i|=\ln \left(n F A k^{0} C_{O}\right)+-\alpha n F / R T\left(E-E_{0}\right)$

A Koutecky-Levich plot was also drawn with the experimental data obtained with $\left\{\left[\mathrm{FeTPyP}\left(\mathrm{Crphen}_{2} \mathrm{Cl}\right)_{4}\right]^{8+} / \mathrm{SiW}_{12} \mathrm{O}_{40}{ }^{4-}\right\}_{3} / \mathrm{GC}$ multilayer, inset in Fig. 11. Comparison of this plot with the curve calculated with eqs. 8 - 11, reveals the existence of two different zones. The presence of two zones suggests alterations of the laminar flow when angular rotation rates are higher than 750 r.p.m. This behavior can be explained on the basis of the SEM micrographs obtained for the system. Where the behavior is associated with the microporosity and thickness of the multilayer. Koutecky-Levich plot was drawn using data obtained when rotation rates lower than 750 r.p.m were used on the $\left\{\left[\mathrm{FeTPyP}\left(\mathrm{Crphen}_{2} \mathrm{Cl}\right)_{4}\right]^{8+} / \mathrm{SiW}_{12} \mathrm{O}_{40}{ }^{4-}\right\}_{3} / \mathrm{GC}$ system. The slope is $\mathrm{n}=3.6 \sim 4$ electrons consistent with a four-electron reduction mechanism.

The second order constant $\left(\mathrm{k}_{1}=5.54 \times 10^{6} \mathrm{M}^{-1} \mathrm{~s}^{-1}\right)$ was calculated assuming a four-electron reduction of $\mathrm{O}_{2}$ in the adduct formed between the $\left\{\left[\mathrm{FeTPyP}\left(\mathrm{Crphen}_{2} \mathrm{Cl}\right)_{4}\right]^{8+} / \mathrm{SiW}_{12} \mathrm{O}_{40}{ }^{4-}\right\}_{3} / \mathrm{GC}$ multilayer and $\mathrm{O}_{2}$. The value of $\mathrm{k}_{1}$ is in the same order of magnitude that the second order rate constant calculated above for the $\left\{\left[\mathrm{NiTPyP}\left(\mathrm{Crphen}_{2}\right)_{4}\right]^{8+} / \mathrm{SiW}_{12} \mathrm{O}_{40}{ }^{4-}\right\}_{2}$ system. It must be concluded that adducts between $\mathrm{O}_{2}$ and the central metal ions in the porphyrins rings are formed in both multilayer assemblies at similar rates, but at different potentials.

Additionally, the polarization curves of the \{[FeTPyP $\left.\left.\left(\text { Crphen }_{2} \mathrm{Cl}\right)_{4}\right]^{8+} / \mathrm{SiW}_{12} \mathrm{O}_{40}{ }^{4-}\right\}_{3} / \mathrm{GC}$ multilayer has a Tafel slope 


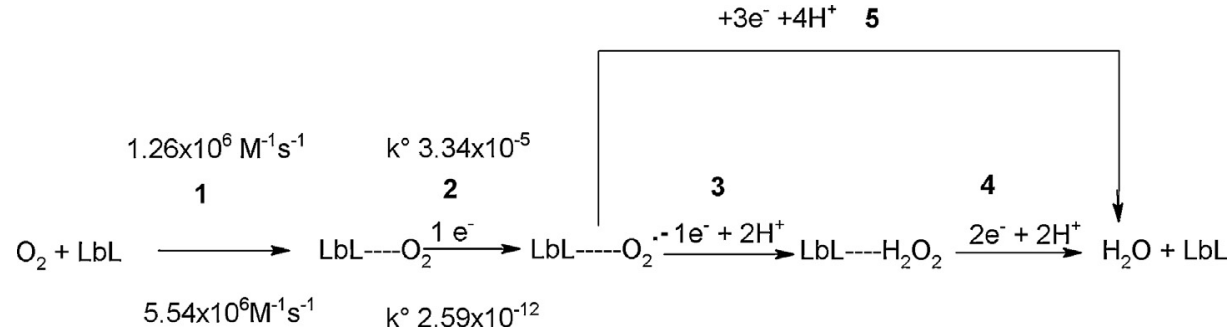

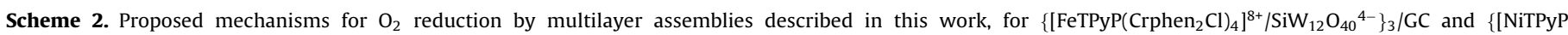
$\left.\left.\left(\text { Crphen }_{2} \mathrm{Cl}\right)_{4}\right]^{8+} / \mathrm{SiW}_{12} \mathrm{O}_{40}{ }^{4-}\right\}_{2} / \mathrm{GC}$.

of $0.115 \mathrm{~V} /$ dec between $+0.25 \mathrm{~V}$ and $+0.15 \mathrm{~V}$ (low polarization regime). The slope value indicates an EC mechanism, where the electrochemical process is the rate determining step [74]. A standard heterogeneous constant, obtained from the intercept of the plot has the value $2.59 \times 10^{-12} \mathrm{~cm} / \mathrm{s}$.

The results obtained with the rotating ring-disk and disk electrodes where the standard heterogeneous constant $\mathrm{k}^{\circ}$ for both systems show that oxygen reduction is accomplished as an irreversible process where the $\left\{\left[\mathrm{FeTPyP}\left(\mathrm{Crphen}_{2} \mathrm{Cl}\right)_{4}\right]^{8+} / \mathrm{SiW}_{12} \mathrm{O}_{40}{ }^{4-}\right\}_{3} / \mathrm{GC}$ assembly is less favored than $\left\{\left[\operatorname{NiTPyP}\left(\mathrm{Crphen}_{2}\right)_{4}\right]^{8+} / \mathrm{SiW}_{12} \mathrm{O}_{40}{ }^{4-}\right\}_{2}$ system. Additionally, the second order rate constant show that oxygen coordinates to central porphyrins with similar rates.

The $\left\{\left[\mathrm{NiTPyP}\left(\mathrm{Crphen}_{2} \mathrm{Cl}\right)_{4}\right]^{8+} / \mathrm{SiW}_{12} \mathrm{O}_{40}{ }^{4-}\right\}_{2} / \mathrm{GC}$ system reduces oxygen by a $\left[2 \mathrm{e}^{-}+2 \mathrm{e}^{-}\right]$mechanism where the generation of the adduct between the multilayer assembly and oxygen is the rate determining step. The latter has been associated with the Tafel slope.

On the other hand, in the oxygen reduction on $\left\{\left[\text { FeTPyP }\left(\text { Crphen }_{2} \mathrm{Cl}\right)_{4}\right]^{8+} / \mathrm{SiW}_{12} \mathrm{O}_{40}{ }^{4-}\right\}_{\mathrm{n}_{\mathrm{i}}} /$ GC (where $\mathrm{n}_{\mathrm{i}}=1,2$ ) the rate responds to a mixed mechanism. The results show that a $\left[2 \mathrm{e}^{-}+2 \mathrm{e}^{-}\right]$step and a direct four electrons operate in these systems. However, the four direct electron transfer predominates in the multilayer with $n_{i}=3$. The results have shown that the oxygen diffusion across the assembly $\left\{\left[\mathrm{FeTPyP}\left(\mathrm{Crphen}_{2} \mathrm{Cl}\right)_{4}\right]^{8+} /\right.$ $\left.\mathrm{SiW}_{12} \mathrm{O}_{40}{ }^{4-}\right\}_{\mathrm{n}_{\mathrm{i}}} / \mathrm{GC}, \mathrm{n}_{\mathrm{i}}=2$ and $\mathrm{n}_{\mathrm{i}}=3$ is important in the mechanism of oxygen reduction. It can be proposed on the basis of these results that the electroactive process present at $\sim+0.2 \mathrm{~V}$ in $\left\{\left[\mathrm{FeTPyP}\left(\mathrm{Crphen}_{2} \mathrm{Cl}\right)_{4}\right]^{8+} / \mathrm{SiW}_{12} \mathrm{O}_{40}{ }^{4-}\right\}_{\mathrm{n}_{\mathrm{i}}} / \mathrm{GC}$ assemblies, is the formation of $\mathrm{Cr}$ (II) on the electrodic surface, controlling the electrocatalysis of the oxygen at more positive potentials than $-0.6 \mathrm{~V}$. These proposed mechanisms are displayed in Scheme 2.

\section{Conclusions}

With a deposition number $\mathrm{n}_{\mathrm{i}}>1$, the $\left\{\left[\mathrm{FeTPyP}\left(\operatorname{Crphen}_{2} \mathrm{Cl}\right)_{4}\right]^{8+} /\right.$ $\left.\mathrm{SiW}_{12} \mathrm{O}_{40}{ }^{4-}\right\}_{\mathrm{n}_{\mathrm{i}}} / \mathrm{GC}$ and $\left\{\left[\operatorname{NiTPyP}\left(\operatorname{Crphen}_{2} \mathrm{Cl}\right)_{4}\right]^{8+} / \mathrm{SiW}_{12} \mathrm{O}_{40}{ }^{4-}\right\}_{\mathrm{n}_{\mathrm{i}}}$ systems, containing non-precious metals, undergo a multilayer assemblage. The effectiveness of the multilayer generation on electrodic surfaces enhances their electrocatalytic activity in reduction of oxygen. Showing synergism between a cationic tetrachromatedmetalloporphyrin and $\mathrm{SiW}_{12} \mathrm{O}_{40}{ }^{4-}$.

In the oxygen reduction, each system responds differently with the applied potential. $\left\{\left[\mathrm{FeTPyP}\left(\mathrm{Crphen}_{2} \mathrm{Cl}\right)_{4}\right]^{8+} /\right.$ $\left.\mathrm{SiW}_{12} \mathrm{O}_{40}{ }^{4-}\right\}_{n_{\mathrm{i}}} / \mathrm{GC}$, (where $\mathrm{n}_{\mathrm{i}}=1,2$,) reduces oxygen to water with a mixed mechanism involving a $\left[2 \mathrm{e}^{-}+2 \mathrm{e}^{-}\right]$step and a direct 4 electron reduction. In contrast to this behavior, the $n_{i}=3$ multilayer reduces oxygen predominantly via direct transfer of four electrons. This effect is probably associated with the in-homogeneity of the multilayer surface onto the electrodic surface.

\section{Acknowledgments}

The authors acknowledge financial support of Project ICMP10-003-F, CILIS, granted by Fondo de Innovación para la Competitividad del Ministerio de Economía, Fomento y Turismo, Chile and FONDECYT Program 1141199 and 11200071 Projects. Part of this research was supported by the University of Notre Dame. The Radiation Laboratory is supported by the Office of Basic Energy Sciences of the US Departmentof Energy. This is Contribution $\mathrm{N}^{\circ}$.NDRL 5033 from the Notre Dame Radiation Laboratory.

\section{Appendix A. Supplementary data}

Supplementary data associated with this article can be found, in the online version, at http://dx.doi.org/10.1016/j.electacta. 2014.08.117.

\section{References}

[1] L.L. Cui, G.J. Lv, Z.Y. Dou, X.Q. He, Fabrication of iron phthalocyanine/graphene micro/nanocomposite by solvothermally assisted pi-pi assembling method and its application for oxygen reduction reaction, Electrochimica Acta 106 (2013) 272-278.

[2] J. Tollefson, Worth its weight in platinum, nature 450 (2007) 1-2.

[3] A. Ishihara, M. Tamura, K. Matsuzawa, S. Mitsushima, K. Ota, Tantalum oxidebased compounds as new non-noble cathodes for polymer electrolyte fuel cell, Electrochimica Acta 55 (2010) 7581-7589.

[4] J.B. Christian, S.P.E. Smith, M.S. Whittingham, H.D. Abruna, Tungsten based electrocatalyst for fuel cell applications, Electrochemistry Communications 9 (2007) 2128-2132.

[5] A.J. Bard, Inner-Sphere Heterogeneous Electrode Reactions. Electrocatalysis and, J. AM. CHEM. SOC. 132 (2010) 7559-7567.

[6] U.I.K. Helmut Tributsch, Iris Dorbandt, A novel non-noble electrocatalyst for oxygen reduction, electrochimica acta 53 (2008) 2198-2209.

[7] F.J.F. Charreteur, S. Ruggeri, J.P. Dodelet, Fe/N/C non-precious catalysts for PEM fuel cells: Influence, Electrochimica Acta 53 (2008) 2925-2938.

[8] J. Maruyama, C. Baier, H. Wolfschmidt, P. Bele, U. Stimming, Enhancement of oxygen reduction at Fe tetrapyridyl porphyrin by pyridyl-N coordination to transition metal ions, Electrochimica Acta 63 (2012) 16-21.

[9] H. Tributsch, Multi-electron transfer catalysis for energy conversion, Electrochimica Acta 52 (2007) 2302-2316.

[10] A. Anastasopoulos, J. Blake, B.E. Hayden, Non-Noble Intertransition Binary Metal Alloy Electrocatalyst for Hydrogen Oxidation and Hydrogen Evolution, Journal of Physical Chemistry C 115 (2011) 19226-19230.

[11] M.S. Ahmed, H. Jeong, J.M. You, S. Jeon, Electrocatalytic reduction of dioxygen at a modified glassy carbon electrode based on Nafion (R)-dispersed singlewalled carbon nanotubes and cobalt-porphyrin with palladium nanoparticles in acidic media, Electrochimica Acta 56 (2011) 4924-4929.

[12] A. Abbaspour, E. Mirahmadi, Electrocatalytic activity of iron and nickel phthalocyanines supported on multi-walled carbon nanotubes towards oxygen evolution reaction, Electrochimica Acta 105 (2013) 92-98.

[13] X.L. Wang, Z.H. Kang, E.B. Wang, C.W.Hu, Preparation, electrochemical property and application in chemically bulk-modified electrode of a hybrid inorganicorganic silicomolybdate nanoparticles, Materials Letters 56 (2002) 393-396.

[14] M.H. Huang, L.H. Bi, Y.Shen, B.F. Liu, S.J. Dong, Nanocomposite multilayer film of preyssler-type polyoxometalates with fine tunable electrocatalytic activities, Journal of Physical Chemistry B 108 (2004) 9780-9786.

[15] P.S. Kishore, B. Viswanathan, T.K. Varadarajan, Synthesis and characterization of metal nanoparticle embedded conducting polymer-polyoxometalate composites, Nanoscale Research Letters 3 (2008) 14-20. 
[16] M.T. Pope, A. Muller, Polyoxometalate chemistry - an old field with new dimensions in several disciplines, Angewandte Chemie-International Edition in English 30 (1991) 34-48.

[17] V. Villari, A. Mazzaglia, M. Trapani, M.A. Castriciano, G. de Luca, A. Romeo, L.M. Scolaro, N. Micali, Optical Enhancement and Structural Properties of a Hybrid Organic-Inorganic Ternary Nanocomposite, Journal of Physical Chemistry C 115 (2011) 5435-5439.

[18] S. Mandal, S. Bhattacharyya, V. Borovkov, A. Patra, Porphyrin-Based Functional Nanoparticles: Conformational and Photophysical Properties of Bis-Porphyrin and Bis-Porphyrin Encapsulated Polymer Nanoparticles, Journal of Physical Chemistry C 115 (2011) 24029-24036.

[19] B. Khlebtsov, E. Panfilova, V. Khanadeev, O. Bibikova, G. Terentyuk, A. Ivanov, V. Rumyantseva, I. Shilov, A. Ryabova, V. Loshchenov, N.G. Khlebtsov, Nanocomposites Containing Silica-Coated Gold-Silver Nanocages and Yb-2,4Dimethoxyhematoporphyrin: Multifunctional Capability of IR-Luminescence Detection, Photosensitization, and Photothermolysis, Acs Nano 5 (2011) 7077-7089.

[20] E.S.M. Sadakane, Chem. Reviews 98 (1998) 219-237.

[21] D.W. Fan, G.B. Li, J.C. Hao, Fabrication and electrocatalytic activities of porphyrin and 12-molybdophosphoric acid hybrid films, Journal of Colloid and Interface Science 351 (2010) 151-155.

[22] D.M. Fernandes, S.M.N. Simoes, H.M. Carapuca, C.M.A. Brett, A.M.V. Cavaleiro, Novel poly(hexylmethacrylate) composite carbon electrodes modified with Keggin-type tungstophosphate-tetrabutylammonium salts, Journal of Electroanalytical Chemistry 639 (2010) 83-87.

[23] D.M. Fernandes, M.E. Ghica, A.M.V. Cavaleiro, C.M.A. Brett, Electrochemical impedance study of self-assembled layer-by-layer iron-silicotungstate/poly(ethylenimine) modified electrodes, Electrochimica Acta 56 (2011) 7940-7945

[24] G. Bazzan, W. Smith, L.C. Francesconi, C.M. Drain, Electrostatic self-organization of robust porphyrin-polyoxometalate films, Langmuir 24 (2008) 3244-3249.

[25] I.Santo, S.L.H. Rebelo, M.S.S. Balula, R.R.L. Martins, M. Pereira, M.M.Q. Simoes, M Neves, J.A.S. Cavaleiro, A.M.V. Cavaleiro, Association of Keggin-type anions with cationic meso-substituted porphyrins: synthesis, characterization and oxidative catalytic studies, Journal of Molecular Catalysis a-Chemical 231 (2005) 35-45.

[26] J.Y. Liu, L. Cheng, B.F. Li, S.J. Dong, Covalent modification of a glassy carbon surface by 4-aminobenzoic acid and its application in fabrication of a polyoxometalates-consisting monolayer and multilayer films, Langmuir 16 (2000) 7471-7476.

[27] L. Cheng, S. Dong, Comparative studies on electrochemical behavior and electrocatalytic properties of heteropolyanion-containing multilayer films prepared by two methods, Journal of Electroanalytical Chemistry 481 (2000) $168-176$

[28] P. Gomez-Romero, M. Chojak, K. Cuentas-Gallegos, J.A. Asensio, P.J. Kulesza, N. Casan-Pastor, M. Lira-Cantu, Hybrid organic-inorganic nanocomposite materials for application in solid state electrochemical supercapacitors, Electrochemistry Communications 5 (2003) 149-153.

[29] D. Ingersoll, P.J. Kulesza, L.R. Faulkner, Polyoxometalate-based layered composite films on electrodes - Preparation through alternate immersions in modification solutions, Journal of the Electrochemical Society 141 (1994) 140-147.

[30] M. García, K. Carfumán, C. Díaz, C. Garrido, I. Osorio-Román, M.J. Aguirre, M. Isaacs, Multimetallic porphyrins/polyoxotungstate modified electrodes by layer-by-layer method: Electrochemical, spectroscopic and morphological characterization, Electrochimica Acta 80 (2012) 390-398.

[31] C.M. Drain, A. Varotto, I. Radivojevic, Self-Organized Porphyrinic Materials, Chemical Reviews 109 (2009) 1630-1658.

[32] R. Arce, R. del Rio, D. Ruiz-Leon, J. Velez, M. Isaacs, M.A. del Valle, M.J. Aguirre, Evidence for the Formation of a Copolymer by Simultaneous Electropolymerization of p-Tetraaminophenyl Porphyrin Cobalt (II)) and o-Phenylenediamine on Glassy Carbon, International Journal of Electrochemical Science 7 (2012) 11596-11608.

[33] F. Armijo, M.C. Goya, Y. Gimeno, M.C. Arevalo, M.J. Aguirre, A.H. Creus, Study of the electropolymerization of tetrakis(3-aminophenyl) porphyrin $\mathrm{Fe}$ (III) chloride on Au electrodes by cyclic voltammetry and STM, Electrochemistry Communications 8 (2006) 779-784.

[34] F. Armijo, M.C. Goya, M. Reina, M.J. Canales, M.C. Arevalo, M.J. Aguirre, Electrocatalytic oxidation of nitrite to nitrate mediated by $\mathrm{Fe}(\mathrm{III})$ poly-3-aminophenyl porphyrin grown on five different electrode surfaces, Journal of Molecular Catalysis a-Chemical 268 (2007) 148-154.

[35] P. Dreyse, M. Isaacs, K. Calfuman, C. Caceres, A. Aliaga, M.J. Aguirre, D. Villagra, Electrochemical reduction of nitrite at poly- $\mathrm{Ru}(5-\mathrm{NO}(2)-$ phen $)(2) \mathrm{Cl}$ tetrapyridylporphyrin glassy carbon modified electrode, Electrochimica Acta 56 (2011) 5230-5237.

[36] K. Calfuman, M.J. Aguirre, B. Matsuhiro, L. Mendoza, M. Isaacs, Electrochemical Reduction of S(IV) Compounds in Water-Ethanol Solutions at Nafion/Tetraruthenated Porphyrins Glassy Carbon Modified Electrodes, Electroanalysis 22 (2010) 338-344.

[37] K. Calfuman, D. Villagra, C. Yanez, B. Matsuhiro, L. Mendoza, M. Isaacs, Nafion/tetraruthenated porphyrin glassy carbon-modified electrode: characterization and voltammetric studies of sulfite oxidation in waterethanol solutions, Journal of solid state electrochemistry 14 (2010) 1065-1072.

[38] K. Calfumán, P. Dreyse, C. García, M.J. Aguirre, T. Beltrán, E. Guillamón, I. Sorribes, C. Vicent, R. Llusar, M. Isaacs, Characterization of PVC-tetraruthenated metalloporphyrins modified electrodes: Application as electrocatalyst in the nitrite reduction, Macromolecular Symposia 304 (2011) 93-100.

[39] K. Calfuman, M.J. Aguirre, P. Canete-Rosales, S. Bollo, R. Llusar, M. Isaacs, Electrocatalytic reduction of nitrite on tetraruthenated metalloporphyrins/Nafion glassy carbon modified electrode, Electrochimica Acta 56 (2011) 8484-8491.

[40] C. Garcia, G. Ferraudi, A.G. Lappin, M. Isaacs, Synthesis, spectral, electrochemica and flash photolysis studies of $\mathrm{Fe}(\mathrm{II}), \mathrm{Ni}$ (II) tetrapyridylporphyrins coordinated at the periphery with chromium(III) phenanthroline complexes, Inorganica Chimica Acta 386 (2012) 73-82.

[41] Carla M.N. Azevedo, Koiti Araki, Lúcio Angnes, H.E. Toma, Electrostatically assembled films for improving the properties of tetraruthenated porphyrin modified electrodes, Electroanalysis 10 (1998) 467-471.

[42] Y. Shen, F. Zhan, J.F. Lu, B.Y. Zhang, D.K. Huang, X.B. Xu, Y.B. Zhang, M.K. Wang, Preparation of hybrid films containing gold nanoparticles and cobalt porphyrin with flexible electrochemical properties, Thin Solid Films 545 (2013) 327-331.

[43] A.M. Smelser, Y.F. Li, C.N. Carmichael, H.Y. Zhao, W.P. Pan, S. Parkin, B.B. Yan, Self-assembly of 1D metalloporphyrin array within pseudo-hexagonal channels of polyoxometalates, Inorganica Chimica Acta 375 (2011) 122-127.

[44] D.T. Sawyer, J.T. Roberts, Experimental electrochemistry for chemist, WileyInterscience, 1974, pp. 208

[45] A. Choi, H. Jeong, S. Kim, S. Jo, S. Jeon, Electrocatalytic reduction of dioxygen by cobalt porphyrin-modified glassy carbon electrode with single-walled carbon nanotubes and nafion in aqueous solutions, Electrochimica Acta 53 (2008) 2579-2584.

[46] U.A. Paulus, T.J. Schmidt, H.A. Gasteiger, R.J. Behm, Oxygen reduction on a highsurface area Pt/Vulcan carbon catalyst: a thin-film rotating ring-disk electrode study, Journal of Electroanalytical Chemistry 495 (2001) 134-145.

[47] Y. Shen, J.Y. Liu, J.G. Jiang, B.F. Liu, S.J. Dong, Fabrication of a metalloporphyrin - Polyoxometalate hybrid film by a layer-by-layer method and its catalysis for hydrogen evolution and dioxygen reduction, Journal of Physical Chemistry B 107 (2003) 9744-9748.

[48] T. Dong, F.W. Chen, J.B. Du, C.W. Hu, A Multilayer Film for Bifunctional Electrocatalyst and Electrochemical Sensor Based on Polyoxometalate and Tris(1,10-Phenanthroline)Ruthenium, Journal of Cluster Science 21 (2010) $779-787$.

[49] D.M. Jean-François Koenig, Applying UV-Vis spectroscopy to step-by-step molecular self assembly, Thin Solid Films 516 (2008) 3865-3872.

[50] P. Kubat, K. Lang, P. Anzenbacher, K. Jursikova, V. Kral, B. Ehrenberg, Interaction of novel cationic meso-tetraphenylporphyrins in the ground and excited states with DNA and nucleotides, Journal of the Chemical Society-Perkin Transactions 1 (2000) 933-941.

[51] P. Kubat, K. Lang, V. Kral, P. Anzenbacher, Preprogramming of porphyrin-nucleic acid assemblies via variation of the alkyl/aryl substituents of phosphonium tetratolylporphyrins, Journal of Physical Chemistry B 106 (2002) 6784-6792.

[52] P. Kubat, K. Lang, K. Prochakova, P. Anzenbacher, Self-aggregates of cationic meso-tetratolylporphyrins in aqueous solutions, Langmuir 19 (2003) 422-428.

[53] W.S. Giorgio Bazzan, Lynn C. Francesconi, C.M. Drain, Electrostatic SelfOrganization of Robust Porphyrin-Polyoxometalate, Langmuir 24 (2008) 3244-3249.

[54] K.M. Kadish, D. Sazou, Y.M. Liu, A. Saoiabi, M. Ferhat, R. Guilard, Inorg. Chem 27 (1988) 1198-1204

[55] C.N. Shi, F.C. Anson, Catalytic pathways for the electroreduction of $\mathrm{O}_{2}$ by iron tetrakis(4-N-methylpyridyl)porphyrin or iron tetraphenylporphyrin adsorbed on edge plane pyrolytic-graphite electrodes, Inorganic Chemistry 29 (1990) 4298-4305.

[56] C.N. Shi, F.C. Anson, Electrocatalysis of the reduction of $\mathrm{O}_{2}$ to $\mathrm{H}_{2} \mathrm{O}$ by tetraruthenated cobalt meso-tetrakis(4-pyridyl)porphyrin adsorbed on graphite electrode, Inorganic Chemistry 31 (1992) 5078-5083.

[57] C.N. Shi, F.C. Anson, Electrocatalysis for the 4-electron reduction of dioxygen based on adsorbed cobalt tetrapyridylporphyrin molecules linked by aquaamine complexes of ruthenium (II), Inorganica Chimica Acta 225 (1994) 215-227.

[58] C. Shi, F.C. Anson, Multiple intramolecular electron-transfer in the catalysis of the reduction of dioxygen by cobalt meso-tetrakis(4-pyridyl)porphyrin to which $4 \mathrm{Ru}\left(\mathrm{NH}_{3}\right)_{5}$ groups are coordinated, Journal of the American Chemical Society 113 (1991) 9564-9570.

[59] C.N. Shi, F.C. Anson, Potential-dependence of the reduction of dioxygen as catalyzed by tetraruthenated cobalt tetrapyridylporphyrin, Electrochimica Acta 39 (1994) 1613-1619.

[60] K. Araki, L. Angnes, C.M.N. Azevedo, H.E. Toma, Electrochemistry of a tetraruthenated cobalt porphyrin and its use in modified electrodes as sensors of reducing analytes, Journal of Electroanalytical Chemistry 397 (1995) 205-210.

[61] K. Araki, H.E. Toma, Electrochemistry of a tetraruthenated iron porphyrin and its electrostatically assembled bilayered films, Electrochimica Acta 44 (1999) 1577-1583.

[62] C.M.N. Azevedo, K. Araki, L. Angnes, H.E. Toma, Electrostatically assembled films for improving the properties of tetraruthenated porphyrin modified electrodes, Electroanalysis 10 (1998) 467-471.

[63] H. Winnischofer, V.Y. Otake, S. Dovidauskas, M. Nakamura, H.E. Toma, K. Araki, Supramolecular tetracluster-cobalt porphyrin: a four-electron transfer catalyst for dioxygen reduction, Electrochimica Acta 49 (2004) 3711-3718.

[64] H.E. Toma, K. Araki, Supramolecular assemblies of ruthenium complexes and porphyrins, Coordination Chemistry Reviews 196 (2000) 307-329.

[65] P.A. Dreyse, M.A. Isaacs, P.E. Iturriaga, D.A. Villagra, M.J. Aguirre, C.P. Kubiak, S.D. Glover, J.C. Goeltz, Electrochemical preparation of conductive films of 
tetrapyridylporphyrins coordinated to four [ $\mathrm{Ru}(5-\mathrm{NO} 2-\mathrm{phen}) 2 \mathrm{Cl}]+$ groups, Journal of Electroanalytical Chemistry 648 (2010) 98-104.

[66] C.T. Carver, B.D. Matson, J.M. Mayer, Electrocatalytic Oxygen Reduction by Iron Tetra-arylporphyrins Bearing Pendant Proton Relays, Journal of the American Chemical Society 134 (2012) 5444-5447.

[67] R.P. Kingsborough, T.M. Swager, Electrocatalytic conducting polymers: Oxygen reduction by a polythiophene-cobalt salen hybrid, Chemistry of Materials 12 (2000), 872-+

[68] K.M. Manesh, P. Santhosh, A.L. Gopalana, K.P. Lee, Electrocatalytic dioxygen reduction at glassy carbon electrode modified with polyaniline grafted multiwall carbon nanotube film, Electroanalysis 18 (2006) 1564-1571.

[69] J.A. Wei Chen, Christian Brückner, Chang Ming Li, Yu Lei, Electrocatalytic FourElectron Reduction of Dioxygen by Electrochemically Deposited, J. Phys. Chem. C 114 (2010) 8633-8638.
[70] H. Shin, D.H. Lee, C. Kang, K.D. Karlin, Electrocatalytic four-electron reductions of $\mathrm{O}-2$ to $\mathrm{H} 2 \mathrm{O}$ with cytochrome c oxidase model compounds, Electrochimica Acta 48 (2003) 4077-4082.

[71] P.J. Kulesza, K. Miecznikowski, B. Baranowska, M. Skunik, A. Kolary-Zurowska, A. Lewera, K. Karnicka, M. Chojak, I. Rutkowska, S. Fiechter, P. Bogdanoff, I. Dorbandt, G. Zehl, R. Hiesgen, E. Dirk, K.S. Nagabhushana, H. Boennemann, Electroreduction of oxygen at tungsten oxide modified carbon-supported RuSex nanoparticles, Journal of Applied Electrochemistry 37 (2007) 1439-1446.

[72] A.J. Bard, L.R. Faulkner, Electrochemical methods, fundamental and applications, John Wiley \& Sons, INC, 2001

[73] A. Schechter, M. Stanevsky, A. Mahammed, Z. Gross, Four-Electron Oxygen Reduction by Brominated Cobalt Corrole, Inorganic Chemistry 51 (2012) 22-24.

[74] S. Fletcher, J. Solid State Electrochem. 13 (2009) 537. 